\title{
LA INFORMACIÓN PARA LA NEGOCIACIÓN COLECTIVA Y EL CONTROL SINDICAL DESDE LA PERSPECTIVA DE LA AUDITORÍA SOCIOLABORAL*
}

\author{
Eva Garrido Pérez \\ Catedrática de Derecho del Trabajo y de la Seguridad Social \\ Universidad de Cádiz
}

Orcid: 0000-0001-7910-4969

Recibido el 30 de septiembre de 2016

DOI: $10.1387 /$ lan-harremanak. 17491

Aceptado el 15 de octubre de 2016

\section{ABSTRACT}

Resumen: En los últimos años se ha asistido a sucesivas reformas y nuevas aportaciones legislativas y judiciales que han dado como fruto una mejor definición de la información a la que los representantes del personal tienen derecho y que la empresa está obligada a proporcionar; una información de distinta naturaleza y alcance, en ámbitos empresariales diferenciados (en grupos o empresas complejas, en sociedades, cooperativas, de dimensión nacional o europeo, etc.), ya sea una información expresamente prevista u otra de implícita exigencia, y ya sea asociada o no al cumplimiento de otros derechos o facultades de intervención de los representantes del personal.

La empresa se encuentra obligada pues por un deber informativo que la norma no siempre define con claros contornos materiales (por los temas o cuestiones sobre los que informar) y temporales (cuándo suministrar información), lo que sin duda ori-

\footnotetext{
* Ponencia presentada en el II Encuentro de Profesionales del Asesoramiento Laboral y Social NEGOCIACIÓN COLECTIVA Y CONTROL SINDICAL. ASPECTOS LABORALES Y ECONÓMICOS, 29 y 30 de septiembre de 2016. Facultad de Relaciones Laborales y Trabajo Social UPVEHU (Leioa).
} 
gina problemas aplicativos en orden al cumplimiento y adecuación de tal deber por parte de la empresa. De ahi que, con independencia de las actuaciones de seguimiento y control que puedan desarrollar los representantes del personal sobre las obligaciones informativas de la empresa, el presente análisis se dirige a contemplar la posible idoneidad de una auditoria externa que reflejara la politica informativa de la empresa, y derivar asi en una estrategia favorecedora de una adecuada gestión de las relaciones laborales en la empresa, a través de una adecuada y suficiente transmisión de información.

Palabras clave: representantes del personal, derechos de información en la empresa, negociación colectiva, control Sindical, información económica y societaria, auditoría sociolaboral.

Abstract: In recent years there have been successive reforms and new legislative and judicial contributions that have resulted in a better definition of the information that the representatives bodies are entitled to and that the company is obliged to provide: information of a different nature and scope, in different business areas (in complex groups or companies, in companies, cooperatives, national or European dimension, etc.), either expressly provided information or another implicit requirement, and associated or not to the fulfillment of other rights or powers of intervention of the workers representatives bodies.

The company is therefore bound by an information duty that the legislation does not always define with clear material outlines (by issues to report) and temporary (when providing information), which undoubtedly gives rise to application problems in order to fulfil such duty by the company. Therefore, independent of the monitoring and control actions that can be developed by the representatives bodies on the information duties of the company, this analysis is aimed to consider the possible suitability of an external audit that reflects the information policy of the company, and thus lead to a strategy favoring an adequate management of labor relations in the company through an adequate and sufficient transmission of information.

Keywords: Workers representative bodies, information rights in the company, collective bargaining. Union control, Economic and corporate information, social-labour audit. 


\section{SUMARIO}

Sumario: 1. Introducción. 2. Reconocimiento del derecho: planteamiento general y orientación finalista. 3. Fundamento jurídico y titulares de los derechos de información en la empresa. 4. Contenidos materiales: información y documentación económica-financiera. 4.1. Planteamiento general: el alcance de la información a suministrar. 4. 2. Información económica general o específica de la empresa. 4.3. Información financiera, contable y societaria. 4.3.1. Ordenación general del ET. a) Documentación financiera y contable: determinación y accesibilidad. b) Información del socio: traslación a los representantes del personal. 4.3.2. Especialidades para las sociedades europeas. 5. Finalidad de la información: la negociación colectiva y el control sindical. 6. A modo de conclusiones: la posibilidad de auditar la información de la empresa. 7. Bibliografía.

\section{Introducción}

Desde un planteamiento de auditoría sociolaboral aplicado a ciertos derechos de información que deben ejercitarse por la empresa y que tienen como sujetos protagonistas a la dirección de la misma y a los representantes de los trabajadores, cabría preguntarse si es posible realmente desarrollar una actividad de auditoría expresada en la promoción, seguimiento y control del cumplimiento de aquellos deberes que se imputan a la empresa de proporcionar determinada información y documentación que ella misma genera, que afecta directamente a su gestión, organización, a su situación económica y financiera, a su estrategia, etc., y que contiene una serie de datos o análisis que pueden tener con frecuencia naturaleza sensible y confidencial. En definitiva, si es posible auditar el sistema de información en la empresa, verificando el grado de cumplimiento de la normativa laboral o convencional al respecto, y emitiendo en su caso informes, dictámenes o análisis de adecuación y promoción de la práctica empresarial en este particular ámbito.

Como apunte inicial podría sugerirse que en pura lógica los propios sujetos titulares de la información, esto es, las organizaciones sindicales y los mecanismos representativos del personal, serían los primeros interesados en el desarrollo de procesos de auditoría sobre los fundamentos prácticos o materiales de actividades propias como la negociación colectiva o el control sindical, esto es, si se está cumpliendo y dando efectividad a los derechos de información en tanto que pilares materiales y procedimentales que posibilitan el derecho de negociación colectiva y la acción sindical de defensa y promoción de los derechos e intereses de los traba- 
jadores en la empresa. En el bien entendido de que se trataría de procesos y sistemas externos o ajenos a los propios sujetos titulares de la información que en todo caso ya cuentan con sus propios mecanismos y medios para constatar y accionar en consecuencia el cumplimiento de aquello que la norma les otorga.

En consecuencia la pregunta es si realmente es factible insertar como elemento a auditar, desde un punto de vista profesional, la información que se debe suministrar por la empresa conforme al marco jurídico laboral; cuestión que a su vez conduciría a aquella otra relativa a cual sería en su caso la finalidad perseguida y el interés a satisfacer con tal auditoría.

Lo primero, pues, a dilucidar con el fin de intentar dar una respuesta a tales cuestiones es precisamente el objeto de lo que se quiera inspeccionar y comprobar su ajuste, adecuación o idoneidad conforme a determinados parámetros de referencia, esto es, la información que debe suministrarse por la empresa, pero no cualquier información, ni tampoco toda aquella que genere una empresa o de la que está en posesión, ni destinada a cualquier sujeto y para cualquier fin.

Así, pues, se hace preciso delimitar exactamente el entorno material, el subjetivo y el finalista de la información, que en su caso podría ser objeto de un proceso de supervisión, examen, control de cumplimiento y adecuación según los términos con los que tal información se reconoce y garantiza. Y lo primero que se observa en sede de información es que no estamos ante un elemento estático o invariable que pueda ser fácilmente identificado y consiguientemente supervisado o fiscalizado.

Por el contrario, la información en la empresa tiene una naturaleza y una morfología sumamente mutable, versátil, dependiente en sus contornos de la acción e influencia de múltiples factores ligados a la propia evolución de las relaciones laborales, a los cambios en los sistemas económicos y productivos, a las variaciones en las estructuras empresariales, al funcionamiento global de los mercados, a las decisiones políticas y económicas, etc. Estos múltiples factores de influencia hacen de la información en la empresa una institución que no encaja fácilmente en un apunte o en una casilla a completar dentro del conjunto de acciones o prácticas que se desarrollan en una empresa. De la propia elasticidad de la información es ejemplo el modo con el que el marco jurídico laboral español ha acogido, reconocido y ordenado esta institución.

Desde una primera aproximación normativa muy limitada en cuanto a la información a suministrar y con una finalidad hasta cierto punto corporativa con los intereses de la empresa, propia de épocas preconstitucionales, se asiste en los últimos años a una auténtica elaboración y reelaboración normativa, que ha permitido dar un mayor alcance cuantitativo y cualitativo a los poderes de información de los representantes en la empresa. Sucesivas reformas y nuevas aportaciones legislativas y judiciales han dado como fruto una mejor definición 
de la información a la que aquéllos tienen derecho y que la empresa está obligada a proporcionar; una información de distinta naturaleza y alcance, en ámbitos empresariales diferenciados (en grupos o empresas complejas, en sociedades, cooperativas, de dimensión nacional o europea, etc.), ya sea una información expresamente prevista $\mathrm{u}$ otra de implícita exigencia, y ya sea asociada o no al cumplimiento de otros derechos o facultades de intervención de los representantes del personal. Es decir, los ámbitos y parámetros delimitadores de los poderes de información en la empresa son muchos y variados, de donde surge la ineludible imposibilidad de abarcarlos todos con ocasión de un concreto análisis de los mismos y, por ende, la necesidad de acotar el perímetro de estudio.

Sobre esta premisa, el planteamiento analítico siguiente se estructura sobre un primer acercamiento al marco de reconocimiento de los derechos de información, para abordar su fundamento y sujetos titulares, y con ello centralizar el foco de atención en aquella información que por su contenido material concentra un importante grupo de datos de la empresa, y que por su funcionalidad puede instrumentalizarse al ejercicio de una negociación colectiva y a un más amplio control de la actuación de la empresa. Un tipo de información que por lo demás y con carácter general es más susceptible de identificación, seguimiento y supervisión desde controles externos, lo que permitirá en su caso llegar a conclusiones sobre la posibilidad e idoneidad de articular procesos de auditoría sobre tal información.

\section{Reconocimiento del derecho: planteamiento general y orientación finalista}

Desde sus más remotos orígenes, los derechos de información se han considerado como formas imperfectas de lo que se dio en llamar Democracia Industrial $^{1}$, término con el que se aludía inicialmente a un tipo de relación empresasindicato sustentada en una negociación colectiva libre y voluntaria, no regulada por la ley, considerando esa negociación un auténtico instrumento de práctica democrática. No obstante, con posterioridad, en términos generales, la Democracia Industrial fue entendida como idea inspiradora para conseguir una intervención activa de los trabajadores en las opciones de la empresa y en las orientaciones de la política económica de las instituciones públicas, y con ello afrontar un compromiso para un diverso gobierno de la empresa y de la economía en su conjunto. En este planteamiento, se insertaban los derechos de información como instrumentos de participación que implicaban una nueva orientación de

\footnotetext{
${ }^{1}$ Una calificación originariamente expresada por Romagnoli (1985: 158-159), pues al considerar la democracia industrial como incompleta, derivaba que "formas incompletas de democracia industrial son principalmente los derechos sindicales de información y control sobre la politica de la empresa».
} 
la conflictividad, sin excluirla (algo esencial en la función y la actuación sindical), a la vez que respetaban el campo de la decisión empresarial. En efecto, los derechos de información habrían de permitir un conocimiento de los aspectos fundamentales de gestión empresarial que posibilitara desarrollar un control sindical destinado a ejercer una influencia, si no es desde el interior de los procesos de decisión, sí al menos desde el exterior de los mismos. Precisamente, su actuación fuera de esos procesos de decisión permitía eludir las temidas limitaciones tanto a la libertad de opción gestora del empresario como a la autonomía del sindicato, alejándolo de una rechazada corresponsabilidad, para permitirle, por el contrario, efectuar una política de control, si se quiere externa, de las decisiones empresariales que, en conexión a esa una nueva orientación de la conflictividad, posibilitase una intervención más propositiva del sindicato. Una intervención, pues, informada y orientada hacia una actuación sindical activa y propositiva, y no meramente negativa o básicamente conflictiva.

A lo largo de los años que han ido moldeando su evolución, su encaje y tratamiento normativo, los derechos de información no han variado de fundamento, manteniendo su caracterización como instrumentos de control sindical, pero sí han visto concretada su delimitación material y finalista al hilo del reconocimiento de sus sujetos titulares y de las competencias atribuidas a éstos.

Por lo pronto, hay que tener en cuenta que existen derechos o poderes expresos de información cuya delimitación ha sido señalada por la norma llegando en algunos casos a definirlos en todos sus términos y condiciones de ejercicio, prefigurando de modo completo sus aspectos tanto formales como materiales o sustantivos. El alcance de este tipo de poderes expresos es notoriamente muy amplio desde el punto de vista cuantitativo y también disperso por su acogida entre distintos textos normativos y reglamentarios. En este sentido, el RD Legislativo $2 / 2015$, de 23 de octubre, por el que se aprueba el Texto Refundido de la Ley del Estatuto de los Trabajadores (en adelante, ET) aparece como la norma básica y general en la materia, pero no exclusiva, por cuanto también son receptores de poderes de tal naturaleza, entre otros, textos como la Ley Orgánica 11/1985, de 2 de agosto, de Libertad Sindical; la Ley 10/1997, de 24 de abril, sobre derechos de información y consulta de los trabajadores en las empresas y grupos de empresa de dimensión comunitaria; la Ley 31/2006, de 18 de octubre, sobre implicación de los trabajadores en las sociedades anónimas y cooperativas europeas; y el Real Decreto 1483/2012, de 29 de octubre, por el que se aprueba el Reglamento de los procedimientos de despido colectivo y de suspensión de contratos y reducción de jornada.

Ahora bien, junto a este mecanismo de reconocimiento positivo expreso de potestades de información, cabe aludir a otros poderes informativos cuya atribución normativa tan solo puede deducirse de otros poderes o facultades reconocidos expresamente por la ley y de la posición jurídica singular que ésta construye. 
Se trata de determinadas potestades de información implícitas, no previstas expresamente en la norma pero que resultan necesarias para el cumplimiento de otras funciones o poderes de los representantes de los trabajadores. Dentro de esta caracterización de informaciones implícitas se encontrarían, sin duda, aquéllas que resultarían obligadas para el ejercicio de poderes expresos de consulta contemplados normativamente (como los previstos, por ejemplo, en los arts. 40 y 41 del ET) o para la adopción de medidas de conflicto colectivo, o para el desarrollo de la negociación colectiva.

Todos estos derechos de información, sean expresos o implícitos, estén o no asociados a particulares facultades interventoras de los representantes, quedan funcionalizados al ejercicio de la función representativa en los diversos ámbitos y en las distintas modalidades en que aquélla se expresa, ya sea mediante una genérica labor de control y seguimiento de las decisiones y actuaciones de la empresa, o ya sea mediante una específica intervención en un período de consultas o en una negociación colectiva. Es decir, toda la información que puedan recibir los representantes por distintos cauces y diversas fuentes se pone al servicio de las actuaciones competenciales de los órganos de representación del personal, sean las que fueren. Esta instrumentalidad o funcionalidad de todos los poderes de información respecto de la función representativa impide, pues, realizar compartimentos materiales y funcionales que ubicaran cada concreta y determinada información en función de la específica finalidad a la que está destinada. Es decir, un informe sobre la situación económica de la empresa o sobre la evolución probable del empleo constituye un elemento cognoscitivo de inequívoca utilidad para los representantes, tanto para afrontar un periodo de consultas sobre traslado, como para adoptar en su caso una huelga, o para negociar un convenio colectivo.

En todo caso obsérvese que en todo este planteamiento jurídico, los derechos de información no aparecen como estrictas fórmulas de participación. La técnica de la participación por información de los trabajadores en sí mismos considerados ha dejado lugar a la información como instrumento de otras formas de participación, las representativas, y es bajo esta apariencia como se ha generalizado y consolidado en nuestro ordenamiento y en otros de nuestro entorno más cercano.

Consiguientemente, es la función representativa, como fórmula de participación en sí, la que se ve beneficiada con los derechos de información, y la que explica en gran medida la configuración de la información como una posición de ventaja, bajo la forma jurídica de derecho, que se reconoce autónomamente a los representantes de los trabajadores.

Por derivación, resulta de igual importancia evaluar el nivel de información al que los representantes de los trabajadores pueden y deben acceder, así como dilucidar cuales son los fines últimos a los que está destinada la posesión de la información, por cuanto ello dependerá precisamente de las funciones y compe- 
tencias que tengan reconocidas y atribuidas dichos representantes. Es decir, hay una conexión instrumental entre la información y la función representativa, la una sirve a la otra, y en consecuencia el alcance de aquélla (en términos cualitativos y cuantitativos) debe venir determinada por los márgenes y ámbitos de actuación en la que la función representativa se desarrolla o expresa.

En definitiva, ha de partirse de la inicial determinación de una previa actividad informativa como derecho / deber, que a su vez queda conectada con los sujetos implicados como titulares, para finalmente poder quedar fijados los iniciales márgenes materiales de la información.

No parece que requiera atención determinar qué sea la información como actividad debida del empresario a los trabajadores y/o sus representantes. Informar es permitir el acceso a datos inherentes a la actividad y al funcionamiento de la empresa, datos que se encuentran en poder del empresario como titular de la organización, y que son naturalmente desconocidos por los trabajadores, pese a que resultan imprescindibles para el desarrollo de una actividad sindical en sentido amplio. Supone, pues, bajar barreras de conocimiento que tradicionalmente han estado alzadas por razones económicas y de poder en el seno de la organización empresarial. La noción técnica y la cotidiana o vulgar de lo que sea información, prácticamente coinciden, de ahí que no se haya cuestionado tanto lo que sea informar como el «si» o el «cómo» informar. Y como mejor se comprueba este hecho es en relación con aquella información que más atañe al centro de decisión y de gestión de una empresa, a su información económica / financiera, siendo la que más ha centralizado el debate de si debe transmitirse, lo que incluye en su caso los márgenes y alcance material de esa información, y cómo ha de suministrarse.

De ahí la necesidad de abordar a continuación la cuestión básica de a quién y por qué habría de concederse por el ordenamiento jurídico un supuesto derecho de información; en definitiva, cuál es el título de atribución de tal poder, para posteriormente determinar "qué» información suministrar y "con qué finalidad», con la idea de centrar el análisis en aquella información tan sumamente esencial y tan ligada al poder empresarial como es la de índole económica, financiera y societaria.

\section{Fundamento jurídico y titulares de los derechos de información en la empresa}

Es sabido que conforme al contrato de trabajo, y en orden a su efectivo y eficaz cumplimiento, el trabajador ostenta ciertos poderes de información oponibles al empresario y que éste, a su vez, ha de observar como deber derivado de la exigencia del cumplimiento regular de sus obligaciones contractuales. 
Pero ello ni explica ni justifica que el empresario tenga que comunicar determinadas informaciones y que se transmitan a ciertos sujetos distintos de los trabajadores individualmente considerados desde la perspectiva contractual, pero sí hay que convenir en que las relaciones trabajador y empresario no se agotan únicamente en los postulados de la relación contractual, sino que es en el sistema organizativo y productivo de la empresa donde tales relaciones van a encontrar concreción y desarrollo. Esta sede distinta de la contractual es, pues, la constituida por el esquema direccional y organizativo de la empresa como unidad económica, y en la que operan los poderes del empresario con un importante margen de libertad y discrecionalidad, hasta el punto de poder limitar o imposibilitar la propia tutela individual de los trabajadores.

Pero tal poder de información se les atribuye no bajo la forma de un derecho subjetivo, y que significaría tanto como reconocer que la información responde a un interés propio y privado de los órganos de representación (y cuya satisfacción también dependería únicamente de un acto libre y voluntario del sujeto titular), sino como un poder jurídico que permite satisfacer unos intereses ajenos, los de la colectividad representada en virtud de la propia función de representación y tutela de intereses ajenos que la norma ha configurado y otorgado a los órganos colectivos. En consecuencia, el poder de información no es más que una potestad funcional propia de los representantes de los trabajadores $y$, por tanto, destinada a satisfacer los fines propios de esa función representativa, esto es, promocionar y proteger los derechos e intereses de los trabajadores.

Ahora bien, desde la posición empresarial, es decir, desde el ejercicio de la autoridad y de los poderes que se expresan y manifiestan en el ámbito de organización y dirección de la prestación de trabajo, habría que precisar los efectos de los poderes de información sobre ese ámbito de libertad de actuación dominado por los intereses económicos o empresariales. Por lo pronto, al situarse los poderes de información fuera del proceso formativo de las decisiones del empresario, se les está privando de toda naturaleza limitativa de determinados actos empresariales, pues no impiden el libre ejercicio de las facultades directivas. Tampoco de por sí son instrumentos que permitan garantizar una posible modificación de una decisión empresarial para atender a intereses (los de los trabajadores) distintos de aquellos otros de orden económico, estratégico, financiero, etc., que fundamentaron tal decisión.

Aun cuando no son elementos procedimentales limitativos, sí pueden tener otra clara efectividad frente a los poderes empresariales, cual es la de servir de elementos cognoscitivos instrumentales para el ejercicio de otras actividades y derechos representativos que sí gozan de una mayor idoneidad para incidir real y efectivamente sobre el ejercicio de poderes empresariales. Es decir, los poderes informativos sacan a la luz, aunque por lo general restringida o mínimamente, ciertas áreas de decisión y dirección hasta entonces reservadas y de exclusiva po- 
sesión del empresario. Siendo así, ese poder que pudieran obtener los representantes por el cumplimiento de poderes informativos, respecto de determinados actos o decisiones empresariales, solo va a tener eficacia operativa por la utilización de ese sustrato informativo así obtenido cara a otras actuaciones del empresario respecto de las cuales la información que poseen los representantes de los trabajadores terminará actuando a modo de condición de legitimidad e incluso de aceptación de concretas opciones adoptadas por la empresa, y correlativamente permitirá a los representantes operar un control externo limitativo del libre ejercicio del poder del empresario en determinadas actuaciones de éste. Una consideración que encuentra una de sus mejores evidencias en el ámbito de la negociación colectiva o en el de la adopción de acuerdos de flexibilidad interna y reestructuración, donde la información suministrada aparece como elemento esencial e indispensable para acometer un proceso de negociación o consultivo que sí es condicionante o limitativo del poder empresarial de dirección y organización, que se expresa en cambios funcionales o estructurales de afectación colectiva.

Aquello que en todo caso sí debe mencionarse aquí es que, al tratarse de instrumentos de representación, los poderes informativos han de tener como sujeto titular todo órgano o instancia que ostente la condición de representante. En este sentido, y en primer lugar, son indiscutidos sujetos de tales poderes aquéllos que tienen esa condición representativa por institucionalización legal, aun con distinto grado de intervención en el diseño orgánico y funcional de dichos sujetos. Es así como junto a los representantes unitarios (comités de empresa y delegados de personal), que gozan de una regulación legal casi monopolista, se encuentran los delegados sindicales, cuya singular naturaleza jurídica remite necesariamente a la autonomía sindical para la determinación de algunos de sus aspectos orgánicos o de funcionamiento. Reconocimiento institucional legal también reciben las Comisiones Paritarias de vigilancia e interpretación de convenios, los Comités de Seguridad y Salud, los Delegados de Prevención, y especialmente los Comités Intercentros, a los que la norma también instituye como sujetos titulares de poderes de información, aun cuando sea misión de la negociación colectiva completar y desarrollar las previsiones legales en sus respectivos diseños competenciales; sin olvidar lógicamente a los Comités de Empresa Europeos constituidos en España, por situarse aquí la dirección central de una empresa o grupo de empresas de dimensión comunitaria.

Pero situándonos en el esquema básico representativo de nuestro sistema jurídico laboral, son los órganos unitarios y sindicales quienes más claramente expresan la función representativa y cumplen el papel de interlocutores de la empresa, aun cuando ambos tipos de órganos reciben de la ley la titularidad de poderes de información bajo un principio de igualdad de reconocimiento formal y material de tales poderes. 
Expresamente, el art. 10.3 de la Ley Orgánica 11/1985, de 2 de agosto, de Libertad Sindical (en adelante, LOLS) señala que los delegados sindicales que no formen parte del comité de empresa, tendrán derecho a la misma información y documentación que la empresa ponga a disposición de tal comité. Proyecta pues en apariencia un genérico principio de equiparación informativa entre uno y otro órgano que se garantiza por esa doble vía: bien por ser los delegados sindicales miembros del comité de empresa, o bien, en caso contrario, por ese acceso a la misma información y documentación. Es decir, la finalidad de la norma es que el sindicato llegue a conocer a través de sus representantes una información generada en la empresa y que puede resultar necesaria o relevante para el ejercicio de las funciones sindicales. Y si el sindicato no cuenta con presencia en el comité de empresa, cauce normal para acceder a esa información, la norma le garantiza otra vía de acceso, la información directa a sus representantes. En consecuencia, una se plantea como vía subsidiaria de la otra, pero en modo alguno son posibilidades acumulativas. Y esta afirmación arrastra a su vez otra consideración a tener en cuenta en la operatividad práctica de este poder informativo previsto en el art. 10.3 LOLS. En concreto, que el derecho de ser informado por un delegado sindical, como opción alternativa a la no presencia sindical en el comité, no necesariamente tiene que operar en paralelo con el derecho de información del órgano unitario. Al respecto, es cierto que la norma refiere a la "misma» información o documentación, pero de ello no debe interpretarse como una igualdad material de máximos, sino de mínimos. Es decir, aun reconociendo que morfológicamente estamos ante un mismo derecho de recibir información sobre determinadas materias o decisiones, y que se corresponde con un deber jurídico del empresario de informar, sin embargo esta identidad se quiebra ante el fundamento o finalidad de la información, que puede ser distinta según quién sea el titular.

Es cierto que tanto los representantes unitarios como los sindicales ejercen la función representativa, pero para unos $\mathrm{u}$ otros se nutre de facultades, poderes o medios de acción competencial no necesariamente coincidentes, o al menos en contenido, diseño, programación y forma de expresión. De este modo, para los representantes unitarios la información sirve al mejor y más eficaz ejercicio de sus competencias representativas, tal y como éstas han sido delineadas por la norma (legal o convencional); y para los delegados sindicales se funcionaliza al ejercicio de una amplia (y no legalmente delimitada) acción sindical como expresión del derecho mismo de la libertad sindical ${ }^{2}$. Más aun, el derecho de in-

2 Esta distinta funcionalidad, que se imprime al mismo derecho de información en atención a quién sea su distinto titular, es la que obliga, y por tanto justifica, que tal derecho discurra por un plano operativo no necesariamente coincidente dentro de las mismas coordenadas temporales y causales cuando es uno u otro órgano el que lo actúa. Es decir, por ejemplo el hecho de que el comité de empresa no requiera acceder al balance para apoyar un incremento salarial en el seno de la negociación de un convenio colectivo, no puede impedir negárselo al delegado sindical que lo demanda para apoyar en su caso una propuesta de nuevas contrataciones como expresión de una programada acción sindical en la empresa. 
formación de los representantes sindicales se asocia ineludiblemente a la actividad sindical que se inserta en el núcleo mínimo del derecho de libertad sindical. Al formar parte de éste, los poderes de información de los delegados sindicales van a gozar de una especial garantía y protección de la que carecen los representantes unitarios cuando ejercitan incluso los mismos poderes, en particular la posibilidad de aducir el incumplimiento por parte del empresario de sus deberes informativos como una lesión al derecho de libertad sindical, al impedir el pleno ejercicio de la actividad sindical, que es parte esencial de aquel derecho.

Así pues, en la LOLS se observa claramente una técnica de unificar el régimen jurídico de los poderes de información al predicarse de ciertos sujetos no contemplados en el ET. Un tratamiento uniforme cualquiera que sea el ámbito en el que se manifiesten esos poderes o el sujeto que los ejercite. Pero también debe reconocerse que ese inicial tratamiento común, sin embargo, se desvanece una vez traspasadas las puertas normativas para entrar en las judiciales, por cuanto las transgresiones o los incumplimientos de tales poderes sí tendrán distintas consecuencias jurídicas dependiendo del sujeto titular de aquéllos que en concreto quedaran afectado por dichas conductas.

\section{Contenidos materiales: información y documentación económica- financiera}

\subsection{Planteamiento general: el alcance de la información a suministrar}

$\mathrm{Al}$ reconocerse desde la norma los poderes de información atribuidos a los órganos de representación del personal como mecanismos funcionalizados al ejercicio de sus competencias, se ha venido considerando el sometimiento de tales poderes al imperio de la ley, de modo que donde no había un previo reconocimiento normativo de una información, no había un poder de exigirla ni un deber de suministrarla. Una posición que ha mantenido de forma arraigada la jurisprudencia española, partiendo del entendimiento de que los poderes que concede el ordenamiento han de quedar reducidos y limitados en la medida impuesta por la finalidad que determinó su concesión. Ir más allá, y pretender extender los poderes informativos hacia específicos ámbitos de actuación no contemplados por la norma, sobre la base del interés de los trabajadores que con ello se trata de tutelar, ha sido tradicionalmente negado por los tribunales españoles aduciéndose a modo de mantra que "el derecho de información del comité de empresa debe detenerse en los umbrales del derecho empresarial a organizar y planificar el trabajo y a no interferir, más de lo necesario, en lo que es competencia exclusiva de quien da empleo" ${ }^{3}$.

\footnotetext{
${ }^{3}$ Así se expresó por primera vez la sentencia del Tribunal Central de Trabajo de 21 de julio de 1988, seguida de forma indiscutida por otros pronunciamientos del mismo tribunal y de los posteriores Tribunales Superiores de Justicia y Tribunal Supremo.
} 
Sin embargo, no se trata tanto de someterse a la expresividad normativa, sino a una interpretación finalista del conjunto del ordenamiento jurídico en cuanto a la funcionalidad de los poderes que tienen atribuidos los mecanismos de representación del personal. En tal sentido, debe subrayarse que la previsión normativa de los poderes de información viene presidida por un criterio eminentemente funcional, en virtud del cual aquellos poderes se conceden para la satisfacción de determinados intereses, sin que pueda pretenderse apriorísticamente que esta función quede cumplida circunscribiendo su ejercicio a los limitados contenidos materiales seńalados por la norma.

Cierto es que la norma ha incrementado los ámbitos materiales y los contenidos sobre los que recaen poderes de información, pero tampoco con dicha ampliación debe considerarse cerrado el marco de lo que es o debe exigirse para satisfacer la función representativa, cuando ésta justifique y reclame la posesión de determinada información o documentación, aun no estando expresada o recogida en la norma.

Si desde la orilla de la función representativa se reclama este criterio interpretativo de los poderes de información eminentemente funcional, admitiendo una ampliación de los contenidos de aquellos poderes más allá de lo previsto en la norma, cuando así quedara exigido y justificado para el ejercicio de ciertas actividades de defensa y representación, asimismo habría que considerar desde la orilla de la posición empresarial cuál es la información que ha de suministrar por imposición de la norma o por exigencia de la función representativa. Y en este sentido el principal campo de batalla, concentrando el interés de unos en solicitarla y obtenerla y el interés de otros de no transmitirla y mantenerla reservada, se encuentra, sin duda, en la información sobre aspectos económicos y financieros de la empresa.

En este sentido, qué duda cabe que los datos económicos y financieros de la empresa constituyen el sustrato básico que están en el fondo de la gran mayoría de las decisiones y actuaciones empresariales que dan origen a la intervención de los representantes. La notoria dependencia funcional de la información económica y financiera respecto de las actuaciones competenciales de los representantes, se puede apreciar en la amplia dedicación de la norma en identificar y garantizar un importante sustrato informativo de tal naturaleza, que la empresa debe suministrar y los representantes tienen el derecho de solicitar y recibir. Para su exposición resulta, pues, metodológicamente adecuado diferenciar aquella información de índole o naturaleza económica general, de aquella otra más específicamente financiera y contable, que a su vez viene condicionada por la conformación societaria que en su caso podría expresar la empresa.

\subsection{Información económica general o específica de la empresa}

$\mathrm{Al}$ expresar este tipo de información, el art. 64 ET recurre particularmente a la técnica de las menciones genéricas, acogiendo conceptos tan amplios como 
"evolución general del sector económico a que pertenece la empresa», "situación de la producción y ventas de la entidad", "programa de producción" y "evolución probable del empleo en la empresa». A pesar de estas alusiones genéricas de ello no cabe deducir una ambigüedad normativa o una deliberada falta de delimitación material, que facilitara un cierto margen de discrecionalidad de la empresa a la hora de dar concreción de los datos a facilitar. Por el contrario, la lectura debe hacerse en clave positiva desde la comprensión de los derechos de información y la función representativa y, en consecuencia, habría de admitirse que la pretensión estatutaria no ha sido la de agotar con dichas expresiones los contenidos informativos de contenido económico que deben suministrarse por la empresa. $\mathrm{Al}$ respecto, ha de coincidirse en que la empresa es la fuente directa de información económica, y no la persona del empresario, y es por tanto la propia complejidad estructural, organizativa, financiera, etc. de aquélla la que origina un determinado nivel de información, sin que pueda quedar, pues, prefijada apriorísticamente desde la norma. De ello tampoco cabría deducir en modo alguno que el empresario está obligado a suministrar toda la información de naturaleza económica que genere la empresa, pero tampoco está en la voluntad o decisión del empresario el criterio que delimite la capacidad informativa de los representantes, sino que ha de ser precisamente la función representativa, a cuyo beneficio se dispone el derecho de información, el elemento interpretativo último que condicione el acceso a una determinada información, aun cuando no esté expresada por la norma.

En definitiva, aquello que se viene defendiendo es que la pretensión normativa ni es ni ha podido ser la de expresar de forma cerrada y exhaustiva la materia precisa sobre la que debe recaer la obligada información, sino la de dar una mera indicación, de carácter mínimo, de lo que el empresario ha de informar a los sujetos representativos, dejando en última instancia que sean la particular complejidad empresarial y la función representativa que en ella se desarrolla, las que precisen los documentos o informaciones que en su caso, y en su momento, deben ser puestos en conocimiento de los representantes de los trabajadores.

En todo caso, es cierto que la evolución normativa, y especialmente la obligada acogida nacional de directivas y reglamentos comunitarios, ha originado una mayor expresión cualitativa y cuantitativa de aquella información de naturaleza económica que la empresa está obligada a dar a los representantes de los trabajadores. Baste mencionar a este respecto el amplio listado de información y documentación que la empresa ha de poner a disposición de los representantes de los trabajadores a los efectos del periodo de consultas contemplado en supuestos de despido colectivo y de suspensión de contratos y reducción de jornada. En particular la empresa tiene obligación de proporcionar una memoria explicativa de las causas justificativas de tales decisiones, que debe ir acompañada de un importante aporte documental, cuya delimitación varía en función 
de la causa alegada, pero que es de especial intensidad cualitativa y cuantitativa cuando los motivos sean de orden económico, al exigir, entre otros documentos, las cuentas anuales de los dos últimos ejercicios, memoria del ejercicio e informe de gestión, cuentas provisionales, informe técnico sobre el volumen de la previsión de perdidas, la documentación fiscal o contable de la disminución de ingresos durante los tres meses anteriores, etc. ${ }^{4}$

\subsection{Información financiera, contable y societaria}

\subsubsection{Ordenación general del ET}

De conformidad con lo dispuesto por el ET, los representantes unitarios (y por extensión los delegados sindicales, ex art. 10.3 de la LOLS) han de conocer el balance, la cuenta de resultados, la memoria, y en el caso de que la empresa revista la forma de sociedad por acciones o participaciones, de los demás documentos que se den a conocer a los socios y en las mismas condiciones que a éstos.

Una clara intencionalidad normativa de ampliar el campo de conocimiento de los representantes con datos de la situación empresarial, que solo pueden ser deducibles por el acceso a determinados datos contables. Y de nuevo cabría formularse la pregunta del por qué, cuál es el interés que se quiere satisfacer con esta nueva apertura del campo de información empresarial a sujetos no propietarios o socios. Obsérvese que esta previsión normativa aparece ya en el primer redactado del ET en los años 80 como obligada expresión, ya en ese momento, de lo que más adelante se denominaría como la necesidad de transparencia de la empresa, y que en los últimos tiempos se inserta como exigencia de una aludida responsabilidad social empresarial o corporativa.

En efecto, ya en la década de los 80 el ET se hizo eco del interés que reviste una adecuada contabilidad para sujetos distintos de los mismos responsables de la gestión empresarial; una obligada conformación de documentos contables que, en consecuencia, se impone a dichos responsables por una necesidad de trasparencia en la gestión económica y financiera en interés del Estado, acreedores, proveedores, consumidores, trabajadores, etc., es decir, de todos aquéllos que conforman los grupos de interés, los modernos stakeholders en terminología empresarial. Cada uno de ellos podrá funcionalizar esa información contable a los particulares intereses que ostenten y defiendan y, en el caso particular de los representantes de los trabajadores, ha de insistirse en que el interés a satisfacer es el del colectivo protegido, por lo que de la adecuada gestión financiera y contable de la empresa dependerán sus rentas salariales y, en última instancia, el pro-

\footnotetext{
${ }^{4}$ Art. 4 del RD 1483/2012, de 29 de octubre, por el que se aprueba el Reglamento de los procedimientos de despido colectivo y de suspensión de contratos y reducción de jornada.
} 
pio futuro de la actividad empresarial como tal. Distinto es que, como luego se verá, la posesión de esa información permita a los representantes tener un sustrato cognitivo que les habilite para adoptar determinadas actuaciones o posturas negociales o conflictuales, en defensa precisamente de ese interés del colectivo de trabajadores representado.

En todo caso, aquello que debe resaltarse ahora es la técnica utilizada por el ET a la hora de proyectar la información contable y societaria que debe suministrarse a los representantes de los trabajadores, al conjugar una expresa determinación de aquellos documentos obligatorios en la contabilidad empresarial, con un principio de equiparación cognoscitivo entre los representantes y otros sujetos titulares de ciertos derechos de información conforme a reglas de gestión y funcionamiento de empresas societarias bajo la cobertura de la ley que ordena a las sociedades de capital. De este modo, la norma estatutaria obliga a entrar en otras realidades y prácticas jurídicas para identificar y concretar el alcance de lo que ella misma ha reconocido en una remisión integradora a la ordenación mercantil.

\section{a) Documentación financiera y contable : determinación y accesibilidad}

El art. 64.4.a) del ET hace expresa alusión, como objeto de la potestad informativa de los representantes del personal, a tres específicos documentos propios de la contabilidad de la empresa, de obligatoria conformación para todo empresario y de los que cabe deducir, de manera ordenada y adecuada a la actividad de la empresa un seguimiento cronológico de todas sus operaciones, tal como prescribe el art. 25 del Código de Comercio (Real Decreto 22 de agosto de 1885$)^{5}$ : el balance, la cuenta de resultados y la memoria, que según disposición del art. 34.1 del propio Código de Comercio conforman las cuentas anuales de la empresa, que debe formular todo empresario al cierre del ejercicio.

Obviamente, la documentación contable de la empresa desengrana y reproduce los pilares sobre los que descansa la gestión económica y financiera de aquélla, con elementos de conformación y justificación esencialmente intrínsecos y, por ello, también más permeables a elementos externos, de ahí que por lo general sean unos documentos y unos datos susceptibles de mantenerse bajo un entorno protegido y reservado. Con un lógico fin protector, el art. 32 del Código de Comercio decreta con carácter general la condición de secreta de la contabilidad de los empresarios, pero lo hace con tal cúmulo de excepciones que

5 En expresión del art. 25, «Todo empresario deberá llevar una contabilidad ordenada, adecuada a la actividad de su Empresa que permita un seguimiento cronológico de todas sus operaciones, asi como la elaboración periódica de balances e inventarios. Llevará necesariamente, sin perjuicio de lo establecido en las leyes o disposiciones especiales, un libro de Inventarios y Cuentas anuales y otro Diario». 
hace realmente difícil preservar la contabilidad de miradas ajenas. Entre las excepciones dispuestas legalmente, y en lo que aquí nos atañe, se menciona no solo la obligación de conocimiento puntual de tales documentos con ocasión de una concreta actuación o procedimiento (como se prevé en caso de suspensiones de pago, quiebra o expedientes de regulación de empleo), sino también la comunicación y reconocimiento general de los libros cuando «los representantes legales de los trabajadores tengan derecho a su examen directo»; un derecho al que da vía libre el Código de Comercio, pero que se concreta en la previsión del ET al proceder a su reconocimiento formal y expreso.

Resultando pues indiscutible, desde la norma, el derecho de los representantes a tener conocimiento de tales documentos, se precisa ahora delimitar el alcance material de tal derecho, es decir, qué informaciones o datos son deducibles de esos documentos, y si al margen de ellos los representantes pueden acceder a otro tipo de información o documentación de naturaleza contable y financiera generada por la empresa, tras lo cual poder confirmar con posterioridad su elemento funcional, esto es, la funcionalidad o instrumentalidad de la información así obtenida por los órganos de representación.

Por lo que se refiere al contenido material de tales documentos, al menos en su delimitación general, la normativa de referencia no recurre a ningún tipo de ambages, y como expresión de claros principios finalistas de transparencia de gestión y seguridad jurídica se dedica en extenso al alcance de los documentos contables que acoge y ordena.

Por lo pronto, de forma inicial y básica, el art. 34.2 del Código de Comercio exige que esos documentos que conforman, como se ha dicho, las cuentas anuales, deben "mostrar la imagen fiel del patrimonio, de la situación financiera y de los resultados de la empresa», para a continuación especificar de forma más detallada el contenido y los elementos del balance ${ }^{6}$ y la cuenta de pérdidas y ga-

${ }^{6}$ Según dispone el art. 35.1 del Código de Comercio, «En el balance figurarán de forma separada el activo, el pasivo y el patrimonio neto. El activo comprenderá con la debida separación el activo fijo o no corriente y el activo circulante o corriente. La adscripción de los elementos patrimoniales del activo se realizará en función de su afectación. El activo circulante o corriente comprenderá los elementos del patrimonio que se espera vender, consumir o realizar en el transcurso del ciclo normal de explotación, así como, con carácter general, aquellas partidas cuyo vencimiento, enajenación o realización, se espera que se produzca en un plazo máximo de un año contado a partir de la fecha de cierre del ejercicio. Los demás elementos del activo deben clasificarse como fijos o no corrientes. En el pasivo se diferenciarán con la debida separación el pasivo no corriente y el pasivo circulante o corriente. El pasivo circulante o corriente comprenderá, con carácter general, las obligaciones cuyo vencimiento o extinción se espera que se produzca durante el ciclo normal de explotación, o no exceda el plazo máximo de un año contado a partir de la fecha de cierre del ejercicio. Los demás elementos del pasivo deben clasificarse como no corrientes. Figurarán de forma separada las provisiones u obligaciones en las que exista incertidumbre acerca de su cuantía o vencimiento». Específicamente el art. 36.1 se dedica a detallar aquello que se entiende por activos, pasivos y patrimonio neto. 
nancias ${ }^{7}$, contrastando con la mención genérica a la memoria ${ }^{8}$. Estas referencias iniciales deben completarse en todo caso con aquéllas que se incluyen en la normativa específica aplicable a las sociedades en función de su naturaleza y conformación jurídica, pues dependiendo de si la empresa conforma una sociedad anónima o una sociedad limitada, las previsiones en orden a la documentación contable pueden resultar diferenciales.

Al margen de considerar y tener en cuenta estas peculiaridades que presenta la normativa aplicable en función de la tipología de empresa societaria, hay una cuestión común a debatir y dilucidar en relación a los documentos que deben ser conocidos por los representantes: si el poder informativo que les concede la norma en tal sentido se limita a aquellos documentos mencionados expresamente por la misma, o por el contrario aquél se extiende a otros datos o documentos que reflejen la contabilidad o situación financiera de la empresa, y por tanto resultan igualmente exigibles.

Por lo pronto, el mismo Código de Comercio menciona otros documentos obligatorios como el libro inventario y el libro diario (art. 25), el estado que refleje los cambios en el patrimonio neto del ejercicio y el estado de flujos de efectivos (ambos documentos solo obligatorios cuando lo establezca una disposición legal, ex art. 34.1), así como el informe de gestión en caso de la sociedad que sea la dominante en un grupo de sociedades (art. 42), el libro de actas para las sociedades mercantiles en general (art. 26.1), el libro registro de acciones nominativas para las sociedades anónimas, y el libro registro de socios para las sociedades de responsabilidad limitada (art. 27.3). Aun así, y tal como confirma la doctrina mercantilista ${ }^{9}$, con esta documentación no queda cerrada la expresión contable, por cuanto la contabilidad de una empresa, y especialmente la de forma societaria, es entendida de forma amplia, abarcando no solo los documentos reseńados por la normativa de referencia, sino cualesquiera otros que la empresa precise para el desarrollo de la actividad económica que constituya su objeto, dada la naturaleza instrumental de la que gozan los documentos contables respecto de aquélla.

7 Por su parte, la cuenta de pérdidas y ganancias «recogerá el resultado del ejercicio, separando debidamente los ingresos y los gastos imputables al mismo, y distinguiendo los resultados de explotación, de los que no lo sean. Figurarán de forma separada, al menos, el importe de la cifra de negocios, los consumos de existencias, los gastos de personal, las dotaciones a la amortización, las correcciones valorativas, las variaciones de valor derivadas de la aplicación del criterio del valor razonable, los ingresos y gastos financieros, las pérdidas y ganancias originadas en la enajenación de activos fijos y el gasto por impuesto sobre beneficios» (art. 35.2. Código de Comercio). Asimismo, en el apartado 2 del art. 36 se concreta qué se entiende por ingresos y gastos como elementos de la cuenta de pérdidas y ganancias.

${ }_{8}$ Tal como dispone el art. 35.5 del Código de Comercio, «la memoria completará, ampliara y comentará la información contenida en los otros documentos que integran las cuentas anuales».

9 Entre otros Broseta (2016: 93-94), y (Sánchez 2015: 78-79). 
Consiguientemente, si los documentos mencionados por el Código de Comercio y demás normativa societaria tienen un carácter de mínimo obligatorio, y en tanto que a ellos se refiere el art. 64.4.a) ET, podría interpretarse el contenido de éste con el mismo carácter. Es decir, el balance, la cuenta de resultados (cuenta de pérdidas y ganancias) y la memoria son los documentos básicos, y por ello obligatorios en toda contabilidad empresarial, de ahí su expresión específica en la norma estatutaria como indicación mínima de lo que debe ser un elemental conocimiento de aquélla por los representantes de los trabajadores, y sin cerrar en consecuencia la posibilidad de acceder a otro tipo de documentos, tanto obligatorios por imposición normativa, como voluntarios porque no los exige la norma, pero sí, en definitiva, la concreta actividad económica de la empresa.

En esencia, la finalidad perseguida por el precepto estatutario es garantizar el conocimiento por los representantes del estado financiero y contable de la empresa en la medida necesaria y suficiente para que aquéllos puedan llegar a deducir los imprescindibles elementos informativos sobre la situación pasada, presente y futura de la actividad económica productiva, aquéllos que constituyen, en suma, la base argumentativa instrumental de sus funciones representativas. Una finalidad cuya satisfacción podría quedar seriamente mermada de entender limitado el conocimiento contable de los representantes tan solo a los documentos reseńados expresamente en el ET. No quiere con ello decirse que los representantes tengan vía libre para introducirse totalmente en el campo de la contabilidad empresarial y acceder a toda información y documentación que la actividad económica genere, pero sí que ésta precisamente es fuente de una serie de datos de ineludible interés para el eficaz cumplimiento de la función representativa y que no puede excusarse tras el filtro limitativo de la expresividad normativa, pudiendo llegar al término medio y óptimo de permitir que los representantes accedan a aquella otra información y documentación contable, distinta de la mencionada en el ET, pero que resultara imprescindible para el ejercicio efectivo y eficaz de acciones o competencias propias de los órganos de representación, esto es, cuando se tratara de un conocimiento directamente funcionalizado, y así acreditado o justificado, para actividades de defensa y tutela de derechos e intereses de los trabajadores ${ }^{10}$.

Esta misma interpretación finalista de la norma que permite concluir en una amplia cobertura material de la potestad informativa sobre datos conta-

10 Una apertura informativa, no limitada a la estricta mención normativa, que ya se recoge por ejemplo en el art. 77.1 de la Ley 36/2011, de 10 de octubre, reguladora de la jurisdicción social, al permitir que como acto preparatorio, cualquier sujeto que pretenda demandar o prevea que vaya a ser demandado, puede solicitar del órgano judicial el examen de libros y cuentas o la consulta «de cualquier otro documento que se demuestre imprescindible para fundamentar la demanda o su oposición». 
bles y financieros de la empresa, también cabe aducir para solventar aquellas cuestiones de difícil integración en el aspecto puramente formal de acceso a tales datos.

Una de tales cuestiones se refiere precisamente al modo o procedimiento en que los representantes pueden tener acceso a los documentos referenciados por el ET y, en su caso, aquellos otros que pudieran requerirse y/o darse a conocer. En este sentido, y a diferencia de lo que se especifica para la información de naturaleza societaria, el art. 64.4.a) ET no predispone hacia ningún procedimiento que preceptivamente haya de seguirse para acceder a los documentos contables, dado que no se deriva del ET una obligada remisión a lo que dispusiera al respecto la ordenación mercantil ${ }^{11}$, por lo que cabe deducir y admitir que el ET deja campo libre a que sea la propia práctica empresarial la que defina en cada caso sus concretos cauces formales. Pero cualquiera que sea el régimen que particularmente se articule, ya sea mediante la entrega de copia de los documentos a los representantes, ya sea mediante la exposición de tales documentos en las dependencias empresariales ${ }^{12}$, o ya sea otro distinto procedimiento previsto por y en la empresa, debe siempre ofrecer a los representantes la posibilidad de deducir un análisis de conjunto sobre la estructura económica, organizativa y financiera de la empresa.

Una segunda cuestión de indudable calado que afecta al efectivo acceso a la información contable y financiera, se refiere al alcance del deber del empresario de suministrarla, esto es, si pudieran alegarse motivos o razones de secreto o confidencialidad para oponerse al conocimiento de una determinada documentación, ya sea de la expresada por la norma o ya sea de aquella otra distinta cuyo conocimiento hubiera sido solicitado por los representantes, por cuanto, se recordará, el Código de comercio no circunscribe la reserva a unos concretos y específicos documentos por exclusión de otros, sino que alude en general a la confidencialidad de la contabilidad. Una confidencialidad que se excepciona, entre otros motivos, cuando los representantes puedan acceder a ella por tener derecho; un derecho que no requiere, porque no lo exige así la norma, que sea reconocido expresamente, y en consecuencia podría también

11 Concretamente, el Código de Comercio dedica el art. 33 al "reconocimiento de los libros contables», disponiendo que tal reconocimiento, ya sea general o particular, se hará en el establecimiento del empresario, en su presencia o en la de la persona que comisione, debiendo adoptarse las medidas oportunas para la debida conservación y custodia de los libros y documentos.

12 Una opción ésta que, sin duda, podría plantear ciertas dificultades de orden práctico tratándose de una empresa con varios centros de trabajo: ¿cuál es el «establecimiento" del empresario como lugar para examinar los documentos? De identificar dicho establecimiento con uno solo de los centros o con el domicilio social de la empresa, obligaría a un desplazamiento de los representantes de los trabajadores a una localización que puede estar incluso alejada territorialmente. 
admitirse jurídicamente la posibilidad de un acceso a documentos contables cuando así pueda reconocerse por la norma de forma implícita. Y en tal sentido, es en el propio reconocimiento y respaldo a la función representativa que concede la norma mediante la atribución de ciertos derechos de acción y competencias de intervención para el cumplimiento de dicha función, donde se justifica la existencia de poderes implícitos de información, esto es, de aquéllos que recaen sobre cuestiones, materias o contenidos que aun sin ser mencionados expresamente por la norma, quedan directamente funcionalizados al ejercicio de un derecho o competencia de los representantes, de modo que sin la posesión de esa concreta información o documentación, tal actuación representativa no podría llevarse a cabo en condiciones mínimas de eficacia y efectividad.

Alegándose y acreditándose la conexión funcional o instrumental de determinada información a una concreta actuación representativa, la negativa de la empresa a proporcionarla por la única razón de su falta de constancia expresa en la norma, podría conducir a acciones de carácter administrativo o judicial por supuesto incumplimiento de los derechos de información de los representantes e incluso, en función del sujeto titular del derecho afectado, como posible violación del derecho de libertad sindical.

\section{b) Información del socio: traslación a los representantes del personal}

En el mismo precepto estatutario, se individualiza un ámbito empresarial específico, el constituido por las sociedades por acciones o por participaciones, para construir sobre él una peculiar potestad informativa de los representantes, sustentada sobre el propio derecho de información reconocido a los accionistas. En concreto, dispone el art. 64.4.a) ET que los representantes del personal en una empresa societaria tienen el derecho de conocer los documentos que se den a conocer a los socios y en las mismas condiciones que a éstos.

Efectúa así la norma laboral una clara remisión a la normativa propia en materia societaria, y a la que habrá que recurrir para concretar el alcance de ese principio de equiparación cognoscitiva entre socios y representantes de los trabajadores, a pesar de no ostentar unos y otros igual posición ante la empresa societaria. En este sentido, no es necesario incidir en que la posición jurídica de los socios respecto de la sociedad, caracterizada por la aportación de capital que efectúan aquellos, es la que origina y fundamenta que los socios sean titulares de ciertos intereses particulares y específicos a cuya satisfacción coadyuvan concretos derechos a ellos concedidos entre los que se encuentra el de información. Un planteamiento que sin duda no es posible reproducir tratándose de los representantes de los trabajadores, de donde ese principio de equiparación cognoscitiva en ningún caso se fundamenta en una supuesta 
identidad de intereses entre socios y representantes (más allá del común interés en la buena gestión y marcha de la empresa societaria), y sí a lo sumo en el carácter funcional de la información societaria, bien entendido que los extremos concretos de dicha funcionalidad no son exactamente coincidentes para unos y otros sujetos. En este sentido, el derecho de información de los socios está articulado formal y materialmente a los fines del ejercicio de aquel otro derecho al voto en la Junta General de accionistas, medio específico del que disponen los socios para efectuar la función que les compete de seguimiento y control de la gestión y administración societaria ${ }^{13}$. Tratándose de representantes de los trabajadores, el ET les concede el derecho de acceder a datos e informaciones sobre cuestiones societarias en el entendimiento de su esencialidad y oportunidad para el ejercicio de las funciones representativas que llevan a cabo en el seno de la sociedad y que, indiscutiblemente, no se agotan en el mero control de las gestiones societarias.

Pero precisamente la distinta funcionalidad que para unos y otros reviste la información que puedan recibir, aun pudiendo ser la misma, es la que también justifica que en última instancia la información a suministrar a los representantes no esté sometida al mismo régimen jurídico al que se somete el derecho de información de los socios tal y como está previsto en el RD Legislativo 1/2010, de 2 de julio, por el que se aprueba el texto refundido de la Ley de Sociedades de Capital (en adelante, LSC).

Por lo pronto, tal y como viene entendiéndose desde la doctrina mercantilista, el derecho de información de los socios se descompone en dos facultades distintas entre sí pero complementarias (Pulido, 1997: 17 y ss.). Por un lado, se encontraría aquel derecho de información stricto sensu, es decir, el poder otorgado individuamente a cada socio de obtener determinada información (informes o aclaraciones) previamente a la Junta o durante la misma, respecto de aquellos asuntos que constituyan el orden del día. Tales informaciones o aclaraciones se solicitan y en su caso se obtienen a título personal, para satisfacer intereses igualmente personales e individualizados de aquellos sujetos que las requieren normalmente como instrumento para el ocasional ejercicio del derecho de voto en la Junta (arts. 196 y 197 LSC, tratándose de una sociedad de responsabilidad limitada y una sociedad anónima, respectivamente) ${ }^{14}$. Y por otro lado, se encuentra aquella otra facultad contenida en el art. 272 LSC en relación a la aprobación de las cuentas anuales por la Junta General, y

$13 \mathrm{Al}$ respecto, y en relación al fundamento y funcionalidad de la información que recibe el socio, vid., Pulido (1997: 24 y ss.).

14 Téngase en cuenta, en todo caso, que no necesariamente el ejercicio del derecho de información del socio durante la Junta debe estar funcionalizado al derecho al voto que se expresa en la misma Junta, habida cuenta de que precisamente la respuesta a las solicitudes de información que se viertan por los socios durante la Junta puede producirse con posterioridad a la misma, tal y como prevé y posibilita el art. 182 LSC. 
que se traduce en el derecho de todo socio, a partir de la convocatoria de dicha Junta, de obtener los documentos que precisamente se someten a aprobación de la misma, debiendo hacerse mención de tal derecho en la propia convocatoria. Ciertamente este derecho de examen de determinados documentos se conecta temporalmente con la aprobación de los mismos por la Junta, pero la información que se puede deducir de ellos no tiene por qué estar funcionalizada solo y exclusivamente al ejercicio del voto, pues tal derecho de examen puede efectuarse con independencia de que el accionista acuda y vote en su caso en la Junta.

Esta información estática de la situación y vicisitudes de la sociedad derivada de documentos sometidos a aprobación de la Junta que se ponen a disposición de los socios ${ }^{15}$, y que de por sí pueden ser el objeto de un interés ya general ya particular de sujetos no socios (como el Estado, acreedores, proveedores, etc.), entre los que sin duda se encuentran los trabajadores, es la que ineludiblemente debe ser suministrada también a los representantes en virtud de ese principio de equiparación informativa que ampara el art. 64.4.a) ET. Un igual tratamiento que en consecuencia habría de satisfacerse y darse por cumplido proporcionando a los representantes de los trabajadores el orden del día de la Junta y los documentos correspondientes a los puntos del orden del día que, en su caso, se someten a su aprobación o acuerdo.

La pregunta que de inmediato se suscita es si aquella otra información dinámica que pudieran obtener los socios como resultado del ejercicio de su derecho de información previsto en los mencionados arts. 196 y 197 LSC cae también bajo el amparo de dicho principio. La respuesta a nuestro entender debe ser negativa y el motivo de fondo es de orden sustancial: resulta evidente que el personal interés de uno o varios socios en una determinada información o aclaración sobre algún punto del orden de día de la Junta no exige que sea compartida por el resto de socios ni, en nuestro caso, por el conjunto de los trabajadores. Efectivamente, ese principio de equiparación informativa del ET no puede cubrir en modo alguno la facultad de los representantes de exigir de los administradores (y menos aún de los socios) que se le transmitan todas esas informaciones o aclaraciones que han sido demandadas, particularmente por los socios ante los administradores, con carácter previo a la Junta o durante la misma.

En definitiva, la previsión y el mandato del art. 64.4.a) ET habría de interpretarse como una exigencia de otorgar a los representantes el mismo trata-

15 Y nótese que no solo los documentos correspondientes a las cuentas anuales, sino también otros documentos relativos a aspectos diversos de la vida societaria que deben pasar igualmente por el acuerdo o aprobación de la Junta General, como serían los supuestos de aumento o reducción del capital social (arts. 296 y 318 LSC), la modificación de los estatutos sociales (art. 287 LSC) y la transformación, fusión, escisión o disolución de la sociedad (art. 160 LSC). 
miento que se dispense a los socios a la hora de acceder a la información societaria, tanto en el examen de los documentos que se someten a la Junta ${ }^{16}$, como en la facultad de exigir en su caso a los administradores aquella información o aclaración adicional sobre cuestiones del orden del día de la Junta, en base no a los intereses individuales de los socios, sino en atención a los interés específicos de los representantes que surgen y se fundamentan en el ejercicio de sus funciones de representación. En suma, que los representantes sean también titulares de la misma relación jurídica de contenido informativo que une a socios y administradores.

Una relación que, sin embargo, por lo general ni ha sido reconocida, ni exigida ni satisfecha dando cumplimiento a lo dispuesto en el ET, y que sin duda en ocasiones puede deberse al desconocimiento tanto desde el lado de los representantes como en su caso desde los administradores de una empresa societaria, sobre el alcance y extremos derivados del principio de equiparación informativa impuesto en el ET. Posiblemente, un seguimiento y control de la observancia de tal equiparación a través de instrumentos o procedimientos internos o externos (como una auditoría) aportaría elementos de seguridad en el cumplimiento y efectividad de esta potestad informativa de naturaleza societaria otorgada a los representantes del personal.

\subsubsection{Especialidades para las sociedades europeas}

Desde la década de los 70 ya se constataba un serio interés en el seno de las instituciones comunitarias por afrontar un fenómeno que se advertía cada vez más frecuente y que incidía de forma directa en el funcionamiento del mercado único, como era el de las concentraciones y agrupaciones empresariales. Los diversos y sucesivos intentos comunitarios en pro de la constitución de figuras societarias de dimensión europea para encarar las consecuencias de la internacionalización de los mercados y favorecer la competitividad en la economía europea que se sucedieron durante casi 30 ańos, finalmente tuvieron sus frutos con la adopción del Reglamento 2157/2001, de 8 de octubre, por el que se aprueba el Estatuto de la Sociedad Europea. El Reglamento se configura como una ordenación comunitaria dirigida a posibilitar la constitución de una sociedad europea como resultado de reestructuraciones, concentraciones o fusiones a escala comunitaria, evitando las dificultades de orden jurídico o fiscal que se derivarían por el hecho de que distintos Estados miembros intervengan en tales operaciones. La finalidad del Reglamento no es otra que la de permitir que una sociedad europea funcione como un único operador en toda la UE, con una estructura jurí-

16 Teniendo en cuenta que tales documentos podrán ser obtenidos por los socios «de forma inmediata y gratuita» (art. 272 LSC); un aspecto formal que debe también considerarse, reclamarse y exigirse para los representantes de los trabajadores en virtud de ese principio de equiparación dispuesto por el art. 64.4 ET. 
dica adaptada al mercado en el que opera, y bajo un marco uniforme en cuanto a la legislación y la gestión, evitando tener que adaptarse a la legislación nacional de cada Estado miembro en el que proyecten tener una filial.

Con la finalidad de facilitar y favorecer la constitución de una sociedad europea, el Reglamento ofrece varias opciones a disposición de las sociedades ${ }^{17}$, pero cualquiera que sea la opción efectuada para constituirse en sociedad europea siguiendo el Reglamento comunitario y la normativa espańola de acogida $^{18}$, la nueva estructura societaria debe afrontar la implicación de los trabajadores, incluso como factor condicional para el registro de una sociedad europea. Es decir, las sociedades que quieran constituirse en sociedad europea al amparo de este Reglamento deberán haber adoptado un acuerdo o decisión sobre el sistema de intervención o participación de los trabajadores en la misma, conforme a lo que se dispone en la Directiva 2001/86, de 8 de octubre, que complementa el Reglamento de Estatuto de Sociedad Europea en lo que respecta a la implicación de los trabajadores ${ }^{19}$. Esta Directiva encontró su oportuna transposición en

17 Las opciones a través de las cuales es posible constituir una sociedad europea son: fusión de al menos dos sociedades anónimas sujetas a dos Estados miembros; constitución de sociedad europea holding entre sociedades anónimas o sociedades de responsabilidad limitada, siempre que o bien dos de ellas se encuentren en diferentes Estados miembros, o bien tengan una filial o sucursal en otro Estado miembro al menos dos años antes; constitución de una sociedad europea filial; o transformación de una sociedad anónima en sociedad europea, siempre que cuenta con una filial en otro Estado miembro al menos dos ańos antes.

18 Concretamente, por efecto de la Ley 19/2005, de 14 de noviembre, sobre la sociedad anónima europea domiciliada en Espańa, se introdujo un nuevo capítulo en la entonces Ley de Sociedades Anónimas (RDL 1564/1989, de 22 de diciembre) con el fin de incorporar las precisiones indispensables exigidas por el Reglamento comunitario para la plena operatividad de esta nueva figura societaria en Espańa. Contenido que se ha trasladado en lo esencial a la vigente Ley de Sociedades de Capital, dedicando todo el Título XIII a la Sociedad Anónima Europea (arts. 455 y ss.). Entre sus disposiciones (algunas de las cuales acoge o remite al Reglamento comunitario 2157/2001, de 8 de octubre) refiere al debido sometimiento a la Junta de aquellas situaciones en las que una sociedad anónima española participa en la constitución de una Sociedad Anónima Europea por fusión, holding o por transformación. En este último caso (art. 474) se indica que los administradores redactarán un proyecto y un informe donde se explique y justifique los aspectos jurídicos y económicos de la transformación, indicándose las consecuencias de la misma para accionistas y trabajadores.

19 Si bien la Directiva parte y privilegia la negociación en el seno de la sociedad a la hora de establecer un sistema propio de implicación en cada particular sociedad europea ofrece, no obstante, un abanico opcional de modalidades de implicación. en atención a las variadas formas de reglamentación existentes en los distintos Estados miembros en materia de implicación de los trabajadores: información y consulta a nivel de establecimiento, empresa o grupo, o participación en órganos sociales. La pretensión última de la Directiva es que las Sociedades europeas que se constituyan contemplen todas y cada una de ellas alguna modalidad de implicación de los trabajadores, ya sea una participación «orgánica» (presencia de trabajadores o sus representantes en los órganos sociales) o ya sea una intervención a través de procedimientos de información y consulta, alcanzándose en cada sociedad una de estas formas, bien traspasando a la nueva sociedad europea prácticas de implicación ya existentes con anterioridad, bien mediante un acuerdo que establezca un sistema propio de implicación, o bien mediante la aplicación de las disposiciones subsidiarias que garantizan al menos procedimientos de información y consulta. 
nuestro país en la Ley 31/2006, de 18 de octubre, sobre implicación de los trabajadores en las sociedades anónimas y cooperativas europeas. Y sin entrar aquí en mayores detalles sobre la ordenación que acogen una y otra ${ }^{20}$, sí interesa, no obstante, destacar aquellos de sus contenidos que refieren a ciertos poderes de información de sujetos representantes de los trabajadores en estas estructuras societarias y que recaen sobre datos de naturaleza económica y financiera de estas concretas figuras.

Aun considerando que las disposiciones tanto de la Directiva como de la Ley 31/2006 se disponen subsidiariamente en ausencia de acuerdo en el seno de la sociedad europea sobre cómo o a través de qué modalidad los trabajadores quedan implicados, y sobre los derechos y funciones que tal modalidad en su caso lleve aparejada, debe tenerse en cuenta que la información aparece como medio esencial e ineludible para hacer participar, intervenir y, en suma, implicar a los trabajadores en la vida y gestión de la empresa societaria. De forma particular, el órgano de representación de los trabajadores que en su caso se constituya en el seno de la sociedad europea y que actúe como el interlocutor del órgano competente de esta última, deberá obtener determinada información de diversa naturaleza y alcance atinente a la sociedad.

Por un lado, y en el curso de reuniones con el órgano competente de la sociedad, los representantes de los trabajadores deberán ser informados sobre datos tan relevantes y esenciales en la gestión de la sociedad como es la estructura, situación económica o financiera, evolución probable de las actividades, de la producción y de las ventas, y de las inversiones del conjunto de la sociedad europea; sin olvidar aquellas otras informaciones de gestión y llevanza organizativa y económica de la sociedad con afectación directa o indirecta sobre las relaciones laborales y el empleo, como es la situación y evolución probable del empleo, los cambios sustanciales relativos a la organización, la introducción de nuevos métodos de trabajo o nuevos procesos de producción, los traslados de producción, las fusiones, reducciones de tamaño o cierre de empresas, de establecimiento o de partes importantes de estos, y fundamentalmente los despidos colectivos ${ }^{21}$.

Se contempla, así, todo un extenso abanico de contenidos materiales sobre los que transmitir información a los representantes de los trabajadores y que intenta cubrir todas aquellas cuestiones que afectan al conjunto de la sociedad europea o a cualquiera de sus filiales o establecimientos. Una amplitud informa-

20 Para mayor profundidad en esta temática, véanse mis trabajos Garrido (2002, 2003 y 2006).

21 Cfr. Parte 2. Disposiciones de referencia sobre información y consulta contenidas en el Anexo de la Directiva 2001/86, y art. 17 párrafos 2 y 3 de la Ley 31/2006, incorporando la importante precisión de que el órgano de representación del personal debe ser informado con la debida antelación de aquellas circunstancias excepcionales que afecten considerablemente a los intereses de los trabajadores, y las reuniones de información y consulta han de efectuarse con la antelación necesaria para que se tenga en cuenta el criterio del órgano de representación. 
tiva que viene a coincidir con el mismo ámbito competencial de un comité de empresa europeo tratándose de una empresa o grupo de empresas de dimensión comunitaria. Pero sí hay una novedad informativa para los representantes de los trabajadores en la sociedad europea que no se encuentra en aquéllas y es, precisamente, el derecho que tiene el órgano de representación del personal de recibir el orden del día de las reuniones de los órganos societarios, así como la copia de los documentos presentados a la Junta general de accionistas ${ }^{22}$, en línea así con el derecho previsto en la normativa española en relación a las empresas societarias nacionales, tal y como se acaba de ver.

Aun cuando, en consecuencia, los contenidos materiales que van a recibir los representantes de los trabajadores en una sociedad europea no van a divergir respecto de aquéllos a los que con carácter general acceden los órganos de representación en las empresas o sociedades nacionales, sí debe destacarse aquí, como un pequeño apunte diferencial, la funcionalidad a la que sirven las informaciones y datos obtenidos por los representantes de los trabajadores en una sociedad europea. Obviamente, tales elementos cognoscitivos irán directamente funcionalizados al ejercicio de las competencias que tengan atribuidas dichos órganos de representación y que ejerzan en el seno mismo de la sociedad europea, esto es, a aquellas otras funciones de consulta o negociación que se hayan dispuesto en el concreto acuerdo de constitución del sistema de implicación del personal que opere en la sociedad europea ${ }^{23}$. Pero la información recibida por estos órganos no solo sirve a ellos y al eficaz ejercicio de sus competencias, sino que por efecto del propio mecanismo representativo en el seno de la sociedad debe transmitirse desde aquéllos a quienes sean los representantes del personal en cada una de las filiales o establecimientos de la sociedad europea (aquéllos que, además, han participado en la constitución del órgano representativo interlocutor de la sociedad misma ${ }^{24}$ ) para que a su vez

22 Ibídem. Parte 2 del Anexo de la Directiva y art. 17.2 de la Ley 31/2006, precisando, además, que la convocatoria, en unión de la documentación correspondiente, deberá ser remitida por el órgano competente al órgano de representación con una antelación mínima de un mes.

23 De hecho, la Directiva 2001/86, entre sus disposiciones subsidiarias a seguir en caso de ausencia de acuerdo sobre sistema de implicación, alude a una fase de consultas entre el órgano de representación y el órgano competente sobre las cuestiones que se susciten en el seno de las reuniones entre ellos y en relación con ciertas decisiones o medidas a adoptar por la sociedad. Prevé la Directiva que si, tras esa inicial fase de consultas, el órgano competente de la sociedad decidiera no seguir la opinión o criterio manifestado por el órgano representativo del personal, éste tendrá derecho a reunirse nuevamente con el órgano competente para intentar llegar a un acuerdo como fruto, pues, de una negociación.

24 Tal como señala la Directiva 2001/86 (Parte 1 del Anexo) y reitera el art. 16 de la Ley $31 / 2006$, el órgano de representación del personal que actuará como interlocutor con el órgano competente de la sociedad europea, estará compuesto por trabajadores de la sociedad y de sus centros de trabajo y empresas filiales, elegidos o designados por y entre los representantes de los trabajadores o, en su defecto, por el conjunto de los trabajadores, de conformidad con las legislaciones y prácticas nacionales. 
puedan funcionalizarla al cumplimiento de las funciones y competencias que los representantes nacionales tengan atribuidas conforme a la normativa propia. De tal manera, ante la participación de empresas españolas en una sociedad europea, como filiales o establecimientos de la misma, los representantes de los trabajadores de aquéllas podrán intervenir en la constitución del órgano de representación en el seno de la sociedad europea, a la vez que se considerarán representados por dicho órgano, y en suma podrá operar una transmisión informativa de lo conocido por uno hacia los otros, para su oportuna instrumentalización a los respectivos cometidos representativos.

Una transmisión informativa que debe reconocerse y garantizarse una vez solventada la cuestión del deber de reserva que recae sobre los miembros del órgano de representación del personal en la sociedad europea, en relación con la información que el órgano competente de la misma le haya suministrado con carácter confidencial. En este sentido, aun cuando tanto la Directiva 2001/86 (art. 8) como la Ley 31/2006 (art. 22) aluden a la no revelación de la información a terceros, tal deber de reserva no ha de alcanzar a los representantes del personal de establecimientos o filiales españoles de la sociedad europea por dos razones básicas, una de carácter finalista y otra de orden material. Conforme a la primera, cerrar el circuito de información impidiendo que ésta salga del órgano representativo en la sociedad europea, significaría tanto como negar el propio fin previsto por la normativa comunitaria al ordenar la debida implicación de los trabajadores en una sociedad europea: si a los representantes de los trabajadores de filiales o establecimientos se le niega la posibilidad de acceder a la información que recibe el órgano central de representación, se le está impidiendo en última instancia «implicarse» en la gestión y marcha de la sociedad europea misma, tal y como era, se insiste, el objetivo de la directiva comunitaria; y de acuerdo con la segunda razón, de orden material, si la pretensión del órgano competente de la sociedad europea es preservar legítimamente determinada información del conocimiento ajeno, en atención a específicas razones objetivas ligadas en particular a la defensa de la posición competitiva de la sociedad, debe tenerse en cuenta que los representantes de los trabajadores en filiales o establecimientos nacionales también están sometidos al mismo deber de reserva de la información que hubieran recibido con el carácter confidencial, ya sea directamente del órgano competente de la sociedad o ya sea indirectamente por el órgano de representación del personal que a su vez la recibió de aquél, por lo que la sociedad mantiene su interés preservado e incluso protegido por las correspondientes actuaciones sancionatorias de naturaleza administrativa y/o penal, ante violaciones del deber de secreto o reserva.

No obstante, sí debe considerarse los efectos limitativos que para los derechos de información de los representantes de los trabajadores en el seno de la sociedad europea (o en su caso de los representantes del personal de las sociedades filiales españolas) puede tener la previsión contenida en la Ley 
31/2006 sobre la posible dispensa informativa concedida al órgano competente de la sociedad europea, haciendo uso de la habilitación que al respecto contenía la Directiva 2001/86, esto es, que los Estados miembros pudieran no obligar a los órganos societarios a comunicar aquella información que por su naturaleza pudiera, según criterios objetivos, crear graves obstáculos al funcionamiento de la sociedad europea, sus filiales o establecimientos u ocasionar perjuicios a los mismos (art. 8.2 Directiva). Acogiéndose, pues, a esta previsión, el art. 22 de la Ley 31/2006 permite esa dispensa que, en suma, es la autorización al órgano competente de no transmitir información al órgano de representación, pero lo hace en unos términos que pretenden limitar el uso y recurso de esa dispensa ${ }^{25}$. La misma previsión e idéntico contenido que se trasladó al art. 65.4 del ET para su proyección como regla que excepciona las obligaciones informativas del empresario hacia los representantes unitarios (y también hacia los delegados sindicales por extensión y efecto del art. 10. 3 de la LOLS). En consecuencia, resulta común en uno y otro ámbito de actuación representativo el riesgo de que, a pesar de las condiciones estrictas para el recurso a la dispensa, pueda finalmente impedirse el acceso a una información esencial para la función representativa de defensa de derechos e intereses de los trabajadores en ámbitos societarios, simplemente por considerar de forma amplia e incluso generosa el concepto de secreto y de los términos de obstaculización al funcionamiento de la sociedad y perjuicio a su estabilidad económica.

\section{Finalidad de la información: la negociación colectiva y el control sindical}

En el modelo normativo de los derechos de información es posible individualizar un claro elemento de índole negativo: no han estado concebidos en ningún momento como medios de limitación de los poderes empresariales. Es decir, la norma no los ha configurado como elementos procedimentales en el ejercicio de dichos poderes, quedando éstos salvaguardados de toda afectación directa limitativa que proviniese por el simple reconocimiento expreso o implícito de derechos de información. La vertiente positiva ha estado por lo general más clara y así ha sido en las sucesivas fases históricas por las que ha pasado el reconocimiento de tales derechos, contemplándose básicamente como elemento instrumental destinado a facilitar el cumplimiento de aquellas funciones que, en

25 En concreto señala el art. 22.2 de la Ley 31/2006 que «excepcionalmente, el órgano de control o de administración de la sociedad europea o de una sociedad participante establecida en España no estará obligado a comunicar aquellas informaciones especificas relacionadas con secretos industriales, financieros o comerciales cuya divulgación pudiera, según criterios objetivos, obstaculizar el funcionamiento de la sociedad europea o, en su caso, de la sociedad participante, o de sus respectivos centros de trabajo y empresas filiales, u ocasionar graves perjuicios en la estabilidad económica de éstos. Esta excepción no abarcará aquellos datos que tengan relación con el volumen de empleo en las empresas». 
cada momento, se marcaran para una específica estructura orgánica de representación del personal ${ }^{26}$.

Pero esta visión instrumental, aun siendo positiva, ha impedido sin embargo contemplar la información como un derecho autónomo, no dependiente del cumplimento de señaladas funciones de los órganos de representación, lo que ha conducido también a efectos negativos de no reconocer derechos de información allí donde no hay una competencia asociada y así indicada claramente por la norma. Así ha sucedido particularmente con la información para la negociación colectiva y para un general control sindical, si bien el primer parámetro ha conseguido en los últimos ańos encontrar un mayor margen de reconocimiento y garantía, pero no así en relación al control sindical.

En efecto, la información ya de por sí encuentra su fuente constitucional, aquélla que le proporciona un especial significado y protección, en el art. 37.1 de la $\mathrm{CE}$, en el derecho a la negociación colectiva entre los representantes de los trabajadores y los empresarios, y que tendrá su máxima expresión a través de la obligación de negociar de buena fe. Al respecto, es indiscutible que la posesión de una adecuada información se configura como un medio instrumental puesto al servicio de la propia negociación, facilitando que ésta se desarrolle por los cauces y objetivos que de ella se esperan sin la presencia de elementos perturbadores o conflictivos derivados de un defecto o falta de conocimiento. Al legislador español le costó tiempo entender esta conexión, hasta que desde la UE se marcó claramente esta conexión funcional, al entender que difícilmente puede llevarse una negociación colectiva entre empresa y representantes de los trabajadores si éstos no cuentan con los necesarios datos e informes en relación a las específicas materias que son o pueden ser objeto de esa negociación.

Cierto es que la propia intervención normativa de la UE en materia de información en la empresa ha tenido cierto paralelismo con la inicial ordenación española, esto es, contemplando los derechos de información asociados a competencias interventoras de los representantes de los trabajadores, considerándose pues los unos (los derechos de información) como instrumentos de reforzamiento de los otros (los representantes) ${ }^{27}$, lo que se trasladaba consiguien-

26 Así es, por ejemplo, que se concedían poderes informativos a los Jurados Mixtos durante la II Republica, como instrumentos para ejecutar un control del empleo y de la contratación como competencia a ellos atribuida de marcado carácter institucional y político; o aquellos otros derechos de información reconocidos a los Jurados de Empresa en la época franquista, bien para fortalecer el sentido de la solidaridad de los trabajadores en la situación económica de la empresa, reclamada en el régimen de esa época, bien para facilitar su actuación interventora en la elaboración de los reglamentos de régimen interior, o con posterioridad para cumplir con su reconocida capacidad negociadora de convenios colectivos.

27 De lo que es buena prueba la pronta adopción en la década de los 70 de las Directivas sobre despidos colectivos (Directiva 75/129/CEE, de 17 de febrero de 1975) y sobre transmisión de empresa o centros (Directiva 77/1987/CEE, de 14 de febrero de 1977). A ellas siguió ańos más tarde la 
temente, a través de las debidas transposiciones, a las prácticas nacionales de los distintos Estados miembros, y consolidando, así, la técnica de la mención normativa de la información que, en concreto, había de suministrarse a los representantes para el ejercicio de la competencia asociada.

Piénsese, por ejemplo, en todo el conjunto de informaciones y datos que reciben los comités de empresa europeos en empresas o grupos de empresas de dimensión comunitaria, así como los órganos de representación del personal en una sociedad europea, y que por expresa intención de la respectiva normativa de reconocimiento, sirven como elementos instrumentales al ejercicio de las limitadas competencias consultivas que tienen unos y otros, más con una finalidad de que se considere la opción o el criterio de los representantes del personal antes de adoptar o ejecutar una decisión, que con vistas en su caso a la obtención de un acuerdo que no está de por sí ni garantizado ni promocionado, y que de obtenerse, en virtud de la sola voluntad de las partes, habría de tener tan solo una eficacia meramente contractual. Al carecer estos específicos esquemas de representación de otros derechos o poderes, como la negociación de convenios, la adopción de medidas de conflicto o la legitimación para interponer acciones administrativas o judiciales, se corre el riesgo de que la información que reciben, de absoluta importancia y esencialidad desde el punto de vista de la fuente de la que deriva, pueda perder todo su valor y funcionalidad. De ahí la importancia de que a su vez esa información recibida por tales estructuras representativas pueda transmitirse hacia otros esquemas de representación que, conforme a la normativa nacional, sí ostentan o pueden ostentar ese tipo de poderes y, en consecuencia, funcionalizar la información hacia otras intervenciones posibles o futuras, de ámbito más limitado en la línea de la negociación y/o el control de las decisiones empresariales con afectación directa o indirecta en el empleo y las condiciones laborales de los trabajadores.

Pero aun cuando determinados poderes de información han visto incrementado su alcance en atención al órgano representativo (de nueva creación por lo demás) que aparece como su titular, debe agradecerse, sin duda, a la actuación comunitaria el reconocimiento y consolidación de poderes informativos asociados a procesos consultivos y de negociación y que tal instrumentalidad se haya percibido, finalmente, en el ordenamiento jurídico español. Si se observa, el listado de materias sobre las que el empresario debía suministrar información, tal y como aparecía desde su primer redactado en el art. 64 ET, no se conectaba

Directiva 94/45, de 22 de septiembre, sobre comités de empresa europeos, que aun cuando asociaba los derechos de información y consulta a estos nuevos órganos de representación, también preveía su reconocimiento al margen de la existencia de tales comités. La misma idea, derechos de información autónomos o vinculados competencialmente a órganos de representación, se inserta igualmente en la Directiva 2001/86/CE del Consejo, de 8 de octubre de 2001 por el que se completa el Estatuto de la Sociedad Anónima Europea en lo que respecta a la implicación de los trabajadores. 
funcionalmente con procesos consultivos allí donde dichos procesos estuvieran previstos, de modo que tal información resultaba exigible con independencia de que sirviera o no a fines representativos; y a la inversa, pero de forma complementaria, la consulta contemplada en el mismo precepto estatutario se percibía como un derecho autónomo cuyo ejercicio no requería necesariamente la garantía y exigibilidad de determinada información.

Ante esta falta de conexión funcional se recurrió al criterio de la buena fe negocial, ya contemplado en el art. 89.1 ET a los efectos de la negociación colectiva, como recurso argumentativo para exigir al empresario el suministro de aquella información que fuera necesaria a los fines de la negociación y, por extensión, allí donde se contemplaban períodos de consulta, como cualificados mecanismos de negociación colectiva, en la procedimentalización de ciertas decisiones empresariales de afectación colectiva (arts. 40, 41, 47 y 51 ET). Esta fue la opción que empezaron a mantener los tribunales españoles que, aun dominados por el criterio de la expresividad normativa para negar derechos de información que no estuvieran previstos expresamente en la norma, sin embargo sí reconocían la necesidad de contar con la información o documentación necesaria para el desarrollo regular de procesos de consulta o negociación conforme a los dictados de la buena fe. Un criterio que fue propiciado precisamente por esas primeras acciones normativas de la Unión Europea reconociendo derechos de información y consulta con carácter previo a la adopción por el empresario de determinadas medidas, como las Directivas relativas a los despidos colectivos o la constitución de un comité de empresa, tras la que siguió la Directiva Marco de 2002 sobre información y consulta, que pretendía especialmente su incardinación en contextos de modificaciones de condiciones de trabajo y reestructuración empresarial de especial relevancia para los trabajadores.

Han sido pues las iniciativas comunitarias, tanto de orden normativo como jurisprudencial desde el TJUE, las que han conseguido que empiece a asumirse en el sistema espańol la importancia y transcendencia de la información, situándola en un distinto lugar y con un diverso papel en la procedimentalización de ciertas decisiones empresariales de implicaciones en el conjunto de los trabajadores. De ello baste poner el ejemplo significativo de los despidos colectivos. Tradicionalmente el art. 51 ET había venido incluyendo referencias genéricas a la necesidad de acompañar, al escrito de apertura del período de consultas, de la documentación necesaria, remitiendo al oportuno reglamento aplicable la determinación de la misma, lo que solía hacerse en un listado más o menos detallado o amplio de la información o documentación a proporcionar. El último reglamento en materia de procedimentalización de despidos colectivos, el RD 1483/2012, de 29 de octubre, sigue la técnica del listado detallado y exhaustivo de la documentación de diversa naturaleza y alcance que la empresa debe poner a disposición de los representantes del personal, recogiendo y en algunos 
casos ampliando los contenidos materiales que ya se preveían en las normas reglamentarias precedentes, pero eludiendo toda alusión genérica a la información y documentación que fuera necesaria a los fines del periodo de consultas. Esta opción pudo haber llevado al riesgo de interpretar los deberes empresariales de información bajo el criterio de la expresividad normativa de la que hacían buena gala los tribunales españoles y proclives, pues, a no reconocer un derecho de información sobre cuestiones o materias que no estuvieran expresamente mencionadas y previstas por la norma.

Sin embargo, la jurisprudencia del TJUE recaída en conflictos sobre la aplicación de la Directiva 98/59 relativa a despidos colectivos ${ }^{28}$ permitió poner el foco de atención en la efectividad de la función o finalidad asociada al periodo de consultas en un despido colectivo, para considerar así que ha de proporcionarse aquella información o documentación que fuera necesaria y transcendente para dichas consultas. Se da forma, así, a un claro criterio finalista como referente valorativo para identificar cuál sea la información o documentación que fuera pertinente para que el periodo de consultas cumpliera sus funciones; un criterio que pronto empieza a ser acogido por la doctrina judicial española a la hora de valorar los derechos de información y consulta cuando se vinculan funcionalmente en instituciones como las ordenadas en los arts. 40, 41, 47, 51 y 82.3 ET, para sustentar, así, argumentativamente que la finalidad de los requerimientos de información y documentación asociadas a estas instituciones no es otra que la de posibilitar que los representantes de los trabajadores tengan una información suficiente para poder afrontar el periodo de consultas ${ }^{29}$, de donde la información trascendente o pertinente, de obligada transmisión, será aquélla que permita que los representantes puedan tener conocimiento de la situación de la empresa y, en consecuencia, formular propuestas constructivas en tiempo hábil ${ }^{30}$.

28 Desde la perspectiva de preservar el cumplimiento de los fines de la Directiva 98/59 y con ello de los requerimientos de información y consulta que contempla, el TJUE ha afirmado con total claridad que, aun cuando compete a los Estados miembros regular los procedimientos que permita garantizar el cumplimiento de las obligaciones dispuestas en dicha Directiva, "tal regulación no puede privar de eficacia a sus disposiciones", y por ende, "al aplicar el derecho nacional, el órgano jurisdiccional nacional está obligado a interpretarlo, en la medida de lo posible, a la luz de la letra y de la finalidad de la Directiva para alcanzar el resultado que persigue». Cfr. STJCE de 16 de julio de 2009, Asunto Mono Car Styling, C-12/08.

29 En este sentido STS de 20 de marzo de 2013 (recurso núm. 81/2012) y seguida, a su vez, por otras de la misma Sala de 18 febrero 2014 (recurso núm. 74/3013) y de 3 de diciembre de 2014 (recurso núm. 201/2013).

30 SAN de 29 de julio de 2014 (proced. núm. 145/2014), apoyándose en la STJCE de 10 de septiembre de 2009, asunto Fujitsu, C-44/08. En esta misma sentencia se apoya la STSJ de País Vasco de 11 de diciembre de 2012 (proceso núm. 19/2012), para afirmar que "a la luz de la disposición comunitaria que inspira la interna, el juicio de suficiencia de la información facilitada a los representantes de los trabajadores al iniciarse el expediente, debe realizarse atendiendo a la finalidad esencial que justifica la obligación empresarial». 
Es pues esta orientación finalista la que ha facilitado que los tribunales espańoles por lo general asumieran el mismo proceder y la misma lectura en positivo en relación al derecho de información de los representantes de los trabajadores, y que les ha conducido a eludir limitaciones de la documentación que impidiera el cumplimiento del fin propio de la negociación. No obstante, debe precisarse que tal apertura hacia este criterio finalista se produce allí donde alcanza la influencia de la jurisprudencia comunitaria recaída en sede de despidos colectivos, y por extensión en procesos similares de consulta y, por supuesto, de negociación. Pero allí donde las solicitudes de información no quedan asociadas directamente a una actividad representativa previamente identificada o de ejercicio inmediato, los tribunales espańoles por lo general no recurren al mismo criterio de la pertinencia respecto de una general o amplia actividad representativa, sea de control, sea de seguimiento o de evaluación de las decisiones empresariales. Se observa, pues, cierta resistencia a abandonar o simplemente cuestionar el criterio de la expresividad normativa tan anclado en la tradición jurídica española tratándose de derecho de información, y que solo puede superarse cuando los requerimientos informativos y de documentación se analicen y consideren desde la perspectiva de los sujetos titulares y de la función a la que se instrumentalizan, y no desde el planteamiento de una carga o deber de informar del sujeto obligado, que solo puede imponerse expresamente por la norma.

En definitiva, bajo la interpretación judicial delineada entre nuestras fronteras, y en buena parte deudora de la desarrollada a nivel comunitario, la posesión de la oportuna y debida información se reafirma como pieza esencial en la función representativa y en la regularidad de ciertos procedimientos diseñados para el ejercicio de determinados poderes empresariales. A pesar de ello, la doctrina judicial española aún requiere desprenderse de determinadas inercias interpretativas, como es precisamente el criterio de la expresividad normativa, que han imperado en el pasado bajo una distinta configuración contemplativa del derecho de información y que la actual, especialmente auspiciada por las instancias comunitarias, reclama cuanto menos una revisión para acomodarse precisamente a esa funcionalidad y esencialidad que cumplen los poderes de información de los representantes del personal.

\section{A modo de conclusiones: la posibilidad de auditar la información de la empresa}

Como se ha querido poner de manifiesto, la distinta tipología y finalidad de la información complica de manera evidente la opción de listar todas y cada una de las informaciones o documentaciones que la empresa tenga la obligación de proporcionar a los representantes del personal; y paralelamente, por cuanto tales 
poderes informativos son de titularidad de estos representantes e instrumentalizados al ejercicio de sus funciones, son ellos los que directamente han de efectuar un seguimiento y control de la información que han de recibir de la empresa, en el momento requerido y en el que puntualmente así lo exija la función o acción a la que se destine instrumentalmente la información. Sin embargo, el hecho de que los sujetos titulares de la información sean los primeros interesados y legitimados en desarrollar vías de cumplimiento y seguimiento por la empresa de sus obligaciones informativas, no impide de por sí que pudieran desarrollarse procesos externos a los mismos fines, pero considerando las dificultades de tal labor ante las peculiaridades intrínsecas y morfológicas de la información como derecho / deber de naturaleza jurídica.

En este sentido se insiste en que la función genérica de defensa y promoción de los intereses de los trabajadores exige de sus representantes actuaciones o intervenciones de carácter puntual y, en consecuencia, requieren la plena disponibilidad de todos aquellos medios instrumentales que las puedan hacer efectivas, entre ellas, y de modo esencial, la posesión de una adecuada información de tipo económico, financiero o societario. Esta naturaleza puntual y permanente de las atribuciones representativas se contradiría, en términos de efectividad, con el sometimiento del deber de suministrar dicha información a un régimen jurídico caracterizado por delimitados contornos materiales e imperiosos periodos cronológicos. En otras palabras, si la información se funcionaliza a una determinada actividad representativa, ésta es la que en última instancia condicionaría la información a suministrar (esté o no prevista en la norma), así como el momento en que habría de disponerse de la misma, sin sometimiento, pues, a determinados paramentos temporales que ciñan de manera fija el deber informativo.

Así pues, al reconocimiento de la existencia de esos otros poderes implícitos de información que, aun no estando previstos en la norma, resulta igualmente exigibles para la eficacia de la función representativa tal y como se prevé constitucional y legalmente, se añade la ausencia de un rígido formalismo desde la norma en cuanto a los momentos para solicitar y recibir la información prevista expresamente o incluso aquella otra implícita directamente funcionalizada a una concreta actividad representativa. Una ausencia de rigor formal que también cabe proyectar respecto de aquellos poderes informativos para los que la norma sí incluye expresamente una referencia temporal. Es decir, la alusión a una cadencia trimestral para el suministro informativo de las materias contempladas en el art. 64. 2 ET (entre ellas, la evolución general del sector económico al que pertenece la empresa, o sobre la situación económica de la empresa, o el programa de producción), o la cadencia anual para las informaciones previstas en el apartado 3 del mismo artículo (básicamente la información sobre la aplicación del derecho de igualdad y trato entre hombres y mujeres), debe entenderse no con carácter rígido y cerrado, sino como una ga- 
rantía temporal dentro de la cual es necesario informar, siendo posible que la información se suministre en cualquier otro momento, y no solo a instancias del empresario, sino también a solicitud de los representantes, cuando ésta se encuentre justificada por la necesidad de obtener determinada información a efectos de llevar a cabo eficazmente alguna actividad representativa de la índole que fuera.

Ante esa falta de formalidad, tanto material (en cuanto al concreto listado de temas o cuestiones sobre los que la empresa ha de informar) como temporal (por lo que se refiere a los momentos precisos en los que puede solicitarse la información o ésta debe suministrarse por la empresa), se hace prácticamente imposible esbozar un listado cerrado y completo de deberes informativos y su concreta cadencia temporal que resultaran exigibles a la empresa y que, en consecuencia, pudiera someterse a un control o examen externo sobre su cumplimiento y adecuación. Esto no significa, en modo alguno, que tal proceso de examen de auditoría no pudiera llevarse a cabo, solo que necesitaría clarificar los elementos del mismo en lo que se refiere a la información en la empresa.

Obviamente puede listarse toda aquella información y documentación que está mencionada expresamente en la norma (ya sea en el ET, especialmente su art. 64, o en otras disposiciones legislativas y reglamentarias) y comprobar su transmisión a los sujetos titulares de la misma. Pero de forma complementaria, o incluso se diría como núcleo esencial donde concentrar el foco de atención, habría que indagar la política o estrategia que desarrollara la empresa en materia de información hacia los representantes a través de las prácticas o actuaciones que en concreto efectuara. Es decir, más importante que constatar si la empresa proporciona el balance y cuenta de resultados, o un informe sobre producción y ventas, tal y como menciona la norma, es si la empresa practica una clara política de favorecimiento de la información hacia los representantes, proporcionando no solo la que fuera debida, sino también otra que fuera requerida por aquéllos.

Esto es, se trataría de formular ítems de análisis e investigación sobre si la empresa cumple con sus deberes de información hacia los representantes en la medida dispuesta por la norma, si suministra cualquiera otra distinta no mencionada en la misma, bien voluntariamente o bien a solicitud puntual de los propios representantes, y cual sería en tal caso el tipo de información que se proporciona. Con los datos que pudieran extraerse de estos ítems básicos podría efectuarse un análisis o examen subsiguiente, ya de índole más dinámica y funcional, en el sentido de indagar los resultados o los efectos prácticos de la política informativa de la empresa en el marco de las relaciones con los representantes del personal y, por derivación, en la gestión de las más amplias relaciones laborales en la empresa, es decir, su proyección en el desarrollo de procesos consultivos eficaces con los representantes ante la adopción de ciertas decisiones 
empresariales de interés o afectación a los trabajadores, en el desenvolvimiento de una negociación colectiva adecuada y equilibrada a los intereses de ambas partes, en la oportuna gestión de posibles conflictos laborales que pudieran suscitarse en el seno de la empresa y, en definitiva, en la creación de un entorno de confianza y de implicación de los trabajadores en la marcha de la empresa, que redunde positivamente en la misma.

En definitiva, se trata de constatar una aproximación desde la empresa hacia sus deberes informativos con los representantes de los trabajadores como expresión o reflejo de esa más general estrategia de la responsabilidad social corporativa, pero con las debidas cautelas para no confundir u ocultar bajo ésta un sistema de información en la empresa, que tiene un origen claramente normativo $y$, por ende, de una obligatoriedad y vinculabilidad jurídica.

En este sentido, podría llegar incluso a admitirse que algunos de los viejos dictados de la Democracia Industrial aparecen ahora bajo esa nueva forma de la responsabilidad social corporativa al pretender, entre sus objetivos, tener mejor informados a los trabajadores como vía de incrementar su participación en la vida y gestión de la empresa, de hacerles conocedores y partícipes de la marcha de la misma, de sus fines y de sus resultados. Y desde este planteamiento no hay objeción alguna a que un adecuado sistema de información en la empresa pueda constituir un elemento de definición de la responsabilidad social corporativa y bajo dicho marco, en su caso, incorporar elementos de indagación y análisis en procesos de auditoria sociolaboral.

Sin embargo, debe quedar claro que los niveles de información en la empresa no son una opción, es decir, no conforman una supuesta iniciativa voluntaria desde la empresa a los fines de mejorar la implicación y el rendimiento de los trabajadores, y a la que se da forma bajo este entorno estratégico de la responsabilidad social corporativa. Y no lo son por cuanto hay una estructura jurídica de base de reconocimiento y exigibilidad de ciertos poderes informativos que se impone sobre la propia voluntad de la empresa. Desde este punto de vista no es en modo alguno comparable la situación de los derechos de información en Espańa, con la presente en otros países donde al no haber norma alguna que los impongan, son las empresas las que adoptan en su caso una política propiciatoria de la información que puede suministrarse a los trabajadores de tipo económico y societario. Concretamente, en EEUU se está haciendo un seguimiento y análisis de la implantación y efectos de lo que se da en llamar la estrategia del open-document que propicia la entrega a los trabajadores de determinada información empresarial y contable. Conforme a los estudios realizados, solo un porcentaje muy escaso de empresas del país practican esta estrategia, pero, sin embargo, en ellas se constata un notorio aumento del nivel de negocios a raíz de la puesta en práctica de dicha estrategia, por cuanto ha favorecido una mayor implicación de los trabajadores que se ha traducido en un mejor rendimiento y en 
adecuadas y oportunas respuestas a las situaciones empresariales. Como causa o motivo fundamental de la escasa implantación de esta estrategia entre las empresas norteamericanas se apunta el temor de las mismas a que la información suministrada pueda utilizarse en contra de los intereses empresariales o societarios, de donde prima, pues, la reserva de la información frente a los supuestos beneficios de gestión y producción que pudieran derivarse de su suministro a los trabajadores.

Como se observa, en este contexto la ausencia de norma que obligue a suministrar información deja el campo abierto para que objetivos de organización y gestión empresarial sean los que en su caso impulsen una política de información en la empresa y en los términos en que tales objetivos la delimiten y condicionen. En definitiva, si dar o no información, de qué tipo o naturaleza, con qué alcance y en qué condiciones, son términos que dependen en estos contextos solo y exclusivamente de esa libre voluntad o iniciativa de la empresa. Por el contrario, el escenario español es totalmente distinto puesto que es la norma la que delinea esos términos, extrayéndolos de la libre conformación de la empresa, de modo que ésta no puede negarse a reconocer $y$, en consecuencia, dar cumplida efectividad a los poderes de información que normativamente se atribuyen a los representantes de los trabajadores a los fines y competencias que estos tengan atribuidos, sea para la consulta, sea para la negociación, sea para la gestión de situaciones de conflicto o sea para generales actividades de control. Unos poderes que solo tienen como límites la preservación de un interés empresarial de reserva y confidencialidad que objetivamente recaiga sobre datos o informaciones que puedan calificarse, por lo general, como secretos industriales o comerciales. Pero también estos límites que pueden excepcionar la información a recibir, se someten desde la norma a determinados mecanismos de control para evitar su recurso excesivo, inadecuado o desproporcionado.

En conclusión, indiscutiblemente puede someterse a procesos o mecanismos de examen, vigilancia y adecuación un sistema de información en la empresa que refleje si se da información, de qué tipo o naturaleza, si se suministra en cumplimiento de la norma o conjuntamente a solicitud de los representantes, qué motivos se aducen para negar o limitar la información, qué procedimientos formales se arbitran para facilitarla (reuniones, envío documental, intranet, etc.), qué efectos o resultados de índole gestional, económica o laboral se aprecian por la política de información practicada en la empresa, etc. Este tipo de procesos de auditoría externa puede ser, sin duda, un útil espejo donde la empresa vea reflejada su imagen operativa en este ámbito y, en consecuencia, adoptar en su caso determinadas decisiones y criterios de actuación que, no se olvide, deben ir en la línea de reconocer y garantizar aquello que interrelaciona derechos y deberes recíprocos: una adecuada y suficiente información en la empresa. 


\section{Bibliografía}

Broseta Pont, Manuel (2016): Manual de Derecho Mercantil, Tecnos, Madrid.

Garrido Pérez, Eva (2002): «Las modalidades de implicación de los trabajadores en la Sociedad Europea", Revista de Derecho Social, n. ${ }^{\circ} 17$.

Garrido Pérez, Eva (2002): «La Sociedad Europea: un nuevo impulso y una nueva posibilidad para la participación de los trabajadores en las empresas», en AAVV (2003): La dimensión europea y transnacional de la autonomía colectiva, Bomarzo, Albacete.

Garrido Pérez, Eva (2006): «Modelos de Sociedades europeas y disfunciones entre el ordenamiento español y comunitario en materia de participación en la empresa», en AA.VV. (2006): Derecho Social Europeo. Cuadernos de Derecho Judicial XXIII, Consejo General del Poder Judicial.

Pulido Begines, Juan Luis (1997): El derecho de información del socio en la sociedad de responsabilidad limitada, Cívitas, Madrid.

Romagnoli, U. (1985): «L'anno-zero della democrazia industriale», Politica del Diritto, n. ${ }^{\circ} 1$.

Sánchez Calero, Fernando (2015): Instituciones de Derecho Mercantil, Aranzadi, Cizur Menor. 